\title{
Record of Decision \\ based on the \\ Final Environmental Impact Statement \\ for the \\ Flat Canyon Coal Lease Tract (UTU-77114)
}

\author{
USDA Forest Service \\ Manti-La Sal National Forest \\ Ferron-Price Ranger District \\ Sanpete and Emery Counties, Utah
}

January 2002

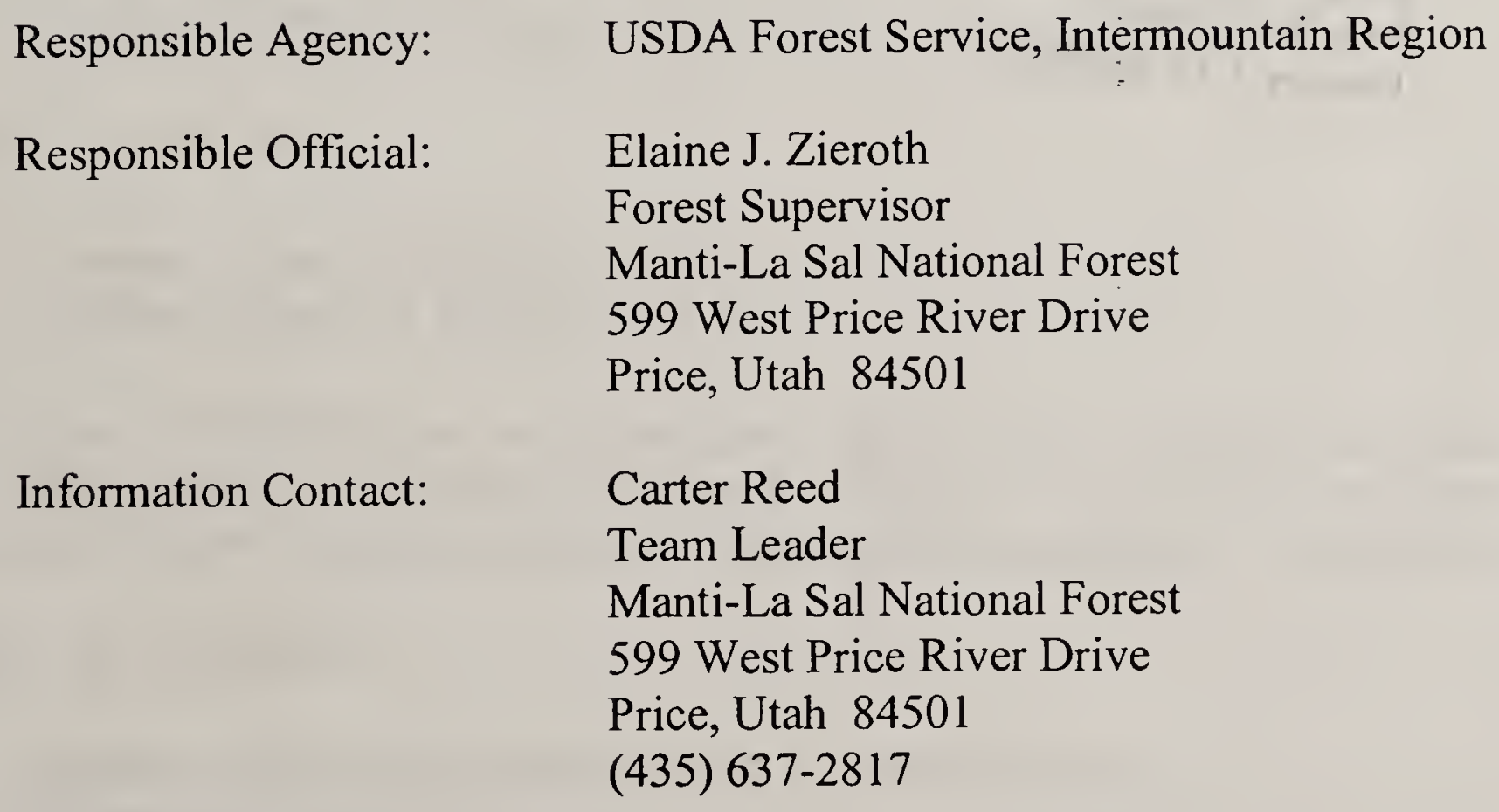


BLM Library

Denver Federal Center

Bldg. 50, OC-521

P.O. Box 25047

Denver, CO 80225 


\section{INTRODUCTION}

\section{A. Proposed Action Overview}

The proposed action is for BLM to offer the Flat Canyon Coal Lease Tract (UTU-77114) for competitive leasing in response to Canyon Fuel's (Canyon Fuel Company, LLC) application for leasing under the Lease-on-Application process contained in Federal Regulations 43 CFR 3425. The purpose of offering the tract for competitive leasing is to provide an opportunity to develop mineable Federal coal reserves by underground methods. Leasing would prevent bypassing mineable coal reserves adjacent to an existing mine that may otherwise not be mined. The coal is needed for the generation of electricity, other industrial uses, and to provide economic returns to the National, State and local economies.

Canyon Fuel's application is to obtain the right to mine known Federal coal reserves in the Flat Canyon Tract, immediately to the west of the current permit area for their Skyline Mine and extend the life of the mine. Canyon Fuel would extend their underground coal workings to the west into the Flat Canyon Tract and beyond into private (fee) coal reserves. It is not likely that any other company would bid on the tract. The coal does not crop out within or adjacent to the tract and the amount of coal available does not economically warrant the cost of developing new portal facilities that would access the coal through a complex of shafts.

The tract was delineated by an Interagency Tract Delineation Team to assure that it is reasonable and meets requirements of the responsible agencies. The Flat Canyon Tract encompasses 2,692.16 acres of Federal coal reserves of the Wasatch Plateau Coal Field on National Forest System lands within the Manti-La Sal National Forest in Sanpete County, Utah. This area is described in the FEIS as the "Tract Area" as follows (FEIS, Figures 1.1 and 1.2):

T. 13 S., R. 6 E., SLM,

Section 21, lots $1-4$, E1/2E1/2;

Section 28, lots $1-8, \mathrm{~S} 1 / 2 \mathrm{NW} 1 / 4$, SW1/4;

Section 33, E1/2, E1/2W1/2, NW1/4NW1/4, SW1/4SW1/4;

T. 14 S., R. 6 E., SLM,

Section 4 , lots $1-4, \mathrm{~S} 1 / 2 \mathrm{~N} 1 / 2, \mathrm{~S} 1 / 2$;

Section 5 , lots $1-4, \mathrm{~S} 1 / 2 \mathrm{~N} 1 / 2, \mathrm{~S} 1 / 2$.

The tract encompasses 2,692.16 acres. Additional non-Federal lands with non-Federal coal (both in private ownership) adjacent to the Federal coal lease tract, referred to as the "Private Lands (approximately 1,100 acres)," could be mined as a result of this lease action. They are described below:

T. 13 S., R. 6 E., SLM,

Section 29, E1/2SE1/4, SE1/4NE1/4, S1/2NE1/4NE1/4;

Section $32, \mathrm{E} 1 / 2 \mathrm{E} 1 / 2$. 
T. 14 S., R. 6 E., SLM,

Section 3 (portion as shown on Figure 1-2)

Section 8, N1/2N1/2;

Section 9, N1/2N1/2;

Section 10 (portion shown on Figure 1-2).

The Tract area and adjacent private lands are collectively referred to in this FEIS as the "Project Area". Therefore, the total area analyzed is approximately 3,792 acres.

\section{B. Decisions to be Made}

The USDI, Bureau of Land Management (BLM) has the leasing authority for all Federal coal reserves under the Mineral Leasing Act of 1920, as amended. The BLM Utah State Director must decide:

- whether or not to offer the Flat Canyon Tract for competitive leasing.

- what terms, conditions, and stipulations are needed on the lease to ensure compliance with the Mineral Leasing Act of 1920, as amended.

The USDA, Forest Service is the Surface Management Agency. The Forest Supervisor, Manti-La Sal National Forest, must decide:

- whether or not to consent to leasing by BLM, under authority of the Mineral Leasing Act of 1920, as amended by the Federal Coal Leasing Amendments Act of 1975.

- what special coal lease stipulations are needed for the protection of non-mineral resources.

The Forest Service decision to consent to leasing, with measures for protection of non-mineral resources, would also allow approval of mining in the tract by the regulatory agencies as long as it is determined (with concurrence of the Forest Service) that the effects to non-mineral resources on National Forest System lands would be consistent with determinations of the FEIS and Forest Service Record of Decision.

Since Forest Service and Bureau of Land Management decisions involve separate and distinct procedures and appeals, the agencies are releasing separate Records of Decision based on the FEIS.

\section{THE DECISIONS}

\section{A. The Selected Alternative}

After careful review of the public comments, the analysis disclosed in the FEIS, and project file, I have decided to select a combination of Alternative B' and C. My decision is hereafter referred to as the "Selected Alternative". The Selected Alternative closely resembles Alternative B' except that (similar to $\mathrm{C}$ ) there would be a limit on the amount of subsidence that could occur beneath perennial streams, 
Boulger Dam and Reservoir, State Route 264, and Flat Canyon Campground on National Forest System lands within the project area. Therefore, I consent to leasing and subsidence of the Flat Canyon Tract, with Forest Service and BLM Special Coal Lease Stipulations (Attachment 1) but subsidence of the areas noted above would be limited to that which would occur from a single-seam of full-extraction mining. This would allow development in two overlapping seams with full-extraction in one seam and only full-support (no subsidence) mining in the second seam within the limited subsidence zones. It would also provide for two overlapping seams of full-extraction mining outside of the limited subsidence zones. The limited-subsidence areas would be established as discussed in Special Coal Lease Stipulation \#9 (Attachment 1). In addition, detailed and comprehensive monitoring of the effects of mining would be required in Forest Service consent/concurrence to approval of the Mining and Reclamation Plan (MRP) and Mine Permit to be issued by the Department of Interior. The lessee/operator would also be required to promptly commence and complete measures specified to mitigate effects. Attachment 2 is a list of monitoring and mitigation requirements that will be incorporated during the MRP and Mine Permit review and approval process.

I did not select Alternative A (No Action) because it would not be consistent with the Presidents Energy Policy and would not make coal reserves available for development consistent with Forest Plan direction, considering that development could occur and direction for management of other resources can likely be achieved. Alternative B was not selected because it would not include Special Coal Lease Stipulations needed to minimize effects to other resources consistent with Forest Plan direction. Alternative B' would include Special Coal Lease Stipulations, but could result in effects of mininginduced subsidence to structures and perennial streams that may not be effectively mitigated.

Alternative $\mathrm{C}$ was not selected because it limited the potential mining area to small blocks that may not be mineable from an economic standpoint and a valuable reserve of coal could be bypassed.

\section{REASONS FOR DECISION}

After reviewing the Flat Canyon Coal Lease Tract FEIS, and examining the issues and effects analysis of the alternatives, I believe that the Selected Alternative provides a reasonable balance between meeting the Nation's energy needs/President Energy Plan, providing socioeconomic benefits to the local communities, State of Utah, and United States, and managing natural resources on National Forest System lands and adjacent non-Federal lands. It however, involves reasonable compromises by limiting the amount of coal that can be mined and allowing short-term, local decreases in recreation opportunities and changes to the natural environment. With required monitoring and mitigation of effects described in Attachment 2, I believe that Forest Plan goals and objectives can be achieved consistent with management direction.

I have chosen the Selected Alternative for the reasons discussed below in this section. Attachment 3 contains corrected and expanded versions of Tables 2.1 (Comparison of Alternatives, Direct Physical Changes Due to Mining) and Table 2.2 (Comparison of Alternatives, Effects by Resource/Issue) in the FEIS. The tables show the effects of the Selected Alternative relative to the other evaluated alternatives. 


\section{A. Achievement of the Forest Plan Goals and Objectives}

The Manti-La Sal National Forest Land and Resource Management Plan (Forest Plan) identifies goals for the management of the Forest. Goals are concise statements describing a desired condition to be achieved some time in the future. Progress is made toward achieving the goals, and their corresponding desired conditions, through implementation of site-specific projects. Projects are designed to achieve specific goals and move toward desired conditions.

\section{B. Meeting the Purpose and Need of the Proposal}

The purpose of offering the tract for competitive leasing is to provide an opportunity to develop mineable Federal coal reserves by underground methods. This coal is needed for the generation of electricity, other industrial uses, and to provide economic returns to the National, State and local economies. If the tract were not leased within the approximate proposed time frame, it is likely that the mineable Federal coal reserves in the project area would be bypassed and not mined in the foreseeable future.

The purpose of Canyon Fuel's application is to obtain the right to mine known Federal coal reserves in the Flat Canyon Tract, immediately to the west of the current permit area for their Skyline Mine. If Canyon Fuel is the successful bidder, they would extend their underground coal workings to the west into the Flat Canyon Tract and beyond into private (fee) coal reserves. This would allow the life of the Skyline Mine to be extended and provide the most efficient mining scenario for available reserves. In addition, mining in the tract would provide needed coal production time to allow potential development of the Winter Quarters Lease (UTU-67939) north of the current permit area without interruption of longwall production mining and associated employment.

My decision would allow production of up to 28 million tons of coal and potentially extend the life of the Skyline mine by up 7 years based on an annual production rate of 4 million tons. This is consistent with Canyon Fuel's current plans for mining the Tract with available mining equipment and would provide more longwall production time than needed to develop underground access to the Winter Quarters Lease (UTU-67939) (3 to 4 years) for future mining.

\section{Forest Plan Goals, Objectives, and Standards}

\section{$\underline{\text { Leaseable Minerals }}$}

A review of the Forest Plan showed that the proposed lease tract area is available for further consideration for coal leasing through application of the Unsuitability Criteria (43 CFR 3464) and an appropriate environmental analysis. (Letter to the Utah State Director of BLM from the Forest Supervisor, Manti-La Sal National Forest 2820-4, January 21, 2000). The Tract lies within the Huntington Canyon-Gentry Mountain coal Multiple-Use Evaluation Area (Forest Plan, pg. C-8). Issues and concerns that must be evaluated for tracts in this area include water quality, traffic, visual quality, and recreation. No areas of the Tract were determined to be unsuitable (FEIS, Appendix F) and the specified issues were evaluated in the FEIS. 
Forest Plan, Page III-35, Minerals Management Leaseable (01) "Negative recommendations, denials, or consent for leasing, permitting, or licensing will be based on site specific environmental assessments using appropriate standards and guidelines. Stipulations for these activities should minimize and/or mitigate effects or conflicts with other resource uses and should return disturbed lands to conditions compatible with the emphasis of the management unit or adjacent management unit."

My decision conforms with this direction. An FEIS was completed for the proposal and I have decided to consent to leasing subject to Special Coal Lease Stipulations prescribed in the Forest Plan, needed to mitigate the effects of leasing/mining consistent with management emphasis for the affected management units. The lease stipulations in combination with Federal Regulations for permitting coal mine operations (30 CFR 700 to end) and the Utah Coal Rules provide for management consistent with emphasis for individual Forest Plan Management Units.

Forest Plan direction for specific management units is address as follows:

\section{RNG (Range) Management Unit}

Minerals Management General (Forest Plan, pg. III-66)

01 "Provide appropriate mitigation measures to assure continued livestock access and use".

It was determined in the FEIS (pg. 2-8) that there would be negligible effects to livestock access and use and this was dismissed as an issue.

02 "Those authorized to conduct developments will be required to replace losses through appropriate mitigations, where a site-specific development adversely affects long-term production or management."

Special Coal Lease Stipulation \#13 requires protection, restoration, or replacement of owned or permitted surface improvements.

\section{$\underline{\text { DRS (Developed Recreation Sites) Management Unit }}$}

Minerals Management General and Minerals Management Leaseable (Forest Plan, pg. III-50)

01 "Manage mineral activities to be compatible with recreation uses and visual quality objectives."

01 "Allow mineral leasing where it is determined that stipulated methods of development and extraction will not adversely affect recreation values to any significant degree."

Flat Canyon Campground is the only DRS Management Unit in the Project Area. It could be closed for one summer use season with additional time needed for repairs due to potential damages from subsidence and safety concerns regarding use of associated facilities during active subsidence. If mined under and subsided during the non-use winter season, it might not be necessary to close it during the following summer-use season unless extensive repairs are necessary. The lessee/operator would monitor the facilities for damages and would be required to make repairs as necessary. The campground would be reopened once utility systems (water/waste water) can safely be operated. During any 
necessary closure, recreation use would be displaced to other available facilities in the area. In addition, the loss or recreation use would be mitigated as required in Attachment 2.

Boulger Reservoir is a popular summer season fishing location, however it was not designated as a DRS Management Unit in the Forest Plan. This facility could be closed and drained for up to 7 years due to potential subsidence damages and safety concerns unless reconstructed to be able to withstand subsidence without significant damage. The latter is an option only if the lessee/operator can demonstrate to the Forest Service and State of Utah that damages would not occur and the Dam could continue to function in a safe manner. The lessee/operator will be required to provide other fishing opportunities to mitigate or offset the effects. If the Dam is breached or damaged, the lessee/operator will be required to reconstruct the Dam to current State standards, dredge the reservoir, and replace/repair the fish ladder following completion of subsidence.

\section{TBR (Timber) Management Unit}

There are no specific requirements for mineral activities in TBR areas (Forest Plan, pg. III-68). No effects from subsidence are expected. Cutting of timber would be avoided when planning exploration and vent shafts. If merchantable timber is cut, the lessee/operator would be required to pay the fair market value for the trees (Special Coal Lease Stipulation \#11. Reclamation would be conducted in a manner consistent with management unit objectives.

\section{WPE (Watershed Protection/Improvement) Management Unit}

Minerals Management General (Forest Plan, pg. III-79)

01 "Restore structural watershed improvements impacted by minerals activities where appropriate."

No effects to this area are expected. If effects should occur, the lessee/operator would be required to protect, restore, or replace any owned or permitted surface improvements. To provide for continuance of current land uses (Special Coal Lease Stipulation \#13).

\section{$\underline{\text { RPN (Riparian) Management Units }}$}

The goals of management are (Forest Plan, pg. III-69) to "(1) maintain water flows to provide free and unbound water within the soil needed to create the distinct vegetative community, (2) provide healthy self-perpetuating plant communities, (3) meet water quality standards, (4) provide habitats for viable populations of wildlife and fish, (5) provide stable stream channels and still water body shorelines, and (6) restore riparian habitats that have been lost through the downcutting of stream channels and wet meadows. The aquatic ecosystem may contain fisheries, habitat improvements, and channel stabilizing facilities that maintain or improve wildlife or fish habitat requirements."

Wildlife Habitat Improvement and Maintenance (Forest Plan, pg. III-70)

01 "Provide habitat diversity through vegetation treatments, and/or structural developments in conjunction with other resource activities, designed to maintain or improve wildlife or fisheries habitat". 
02 "Provide habitat for viable populations of native vertebrate species of fish and wildlife within existing ranges."

03 "Maintain current fish habitat inventory in cooperation with State wildlife agencies."

04 "Provide instream flows to support a sustained yield of natural fisheries resources."

Minerals Management General (Forest Plan, pg. III-72

01 "Avoid and mitigate detrimental disturbance to the riparian area by mineral activities. Initiate timely and effective rehabilitation of disturbed sites."

02 "Where possible, locate mineral activities outside the riparian unit."

03 "Design and locate settling ponds to prevent washout during high water. Locate settling ponds outside of the active channel. Restore channel changes to hydraulic geometry standards for each stream type."

This general direction can be met under the Selected Alternative. By limiting the amount of subsidence of perennial drainages, I believe that the effects can be managed to a level that can maintain viable populations of fish, macroinvertebrates, and other aquatic organisms. Required monitoring would provide information regarding the location and magnitude of effects needing mitigation. Required rehabilitation of affected areas would restore conditions needed to maintain viable populations over the long-term.

\section{$\underline{\text { Land Uses }}$}

Boulger Reservoir and the Flat Canyon Campground are discussed above.

Consultation with the Bureau of Reclamation has determined that there would be no conflicts with the Bureau of Reclamation Withdrawal (personal communication with Bruce Snyder, Bureau of Reclamation, December 19, 2001).

Project scoping (telephone notes, project file) indicated that the private landowners are generally in favor of mining even though some damages to surface facilities are expected from subsidence. Under the Federal Mining Regulations and Utah Coal Rules, the operator would be required to coordinate with surface landowners and repair damages.

Pre-mining land uses would remain the same after mining is completed. As discussed above for specific Forest Plan Management Units, management direction can be met.

\section{Response to Issues Raised}

The following discussions explain how I considered the FEIS issues in making my decisions. The discussions are presented by resource issues as described in Chapter 2, pages 2-3 through 2-8, and Chapter 4 of the FEIS: 


\section{$\underline{\text { Structures and Facilities }}$}

- Mining-induced subsidence and seismicity could damage the Boulger Dam (including the fish ladder) and Reservoir (Significant Issue).

This facility could be closed for up to 7 years due to potential damages from mining-induced seismicity and subsidence and safety concerns or potentially reconstructed prior to mining such that the Dam would withstand seismicity/subsidence without significant damage. See discussion under DRS Management Units above.

I believe that this is an acceptable effect because of the short-term of lost use and the net benefit to recreation uses (including reconstruction/improvement of the dam and improvements to adjacent facilities) that would occur after mining is completed. To offset increased use in other facilities, the lessee/operator would be required to conduct some improvements of these facilities. In addition, Boulger Reservoir is collecting sediment and as a result, degradation of the quality of facility for recreation fishing quality is occurring. Once mining and subsidence are completed and mining is sufficiently distant to prevent continued damages, reconstruction of the Dam to current State standards and dredging of the reservoir would result in a higher quality facility and improved fishing/recreation quality.

- Mining-induced subsidence could damage State Highway 264 (Significant Issue) and Forest Roads (Non-Significant Issue).

The potential damages to these facilities would be reduced by limiting subsidence to that which would occur from one seam of full-extraction mining. The effects would be minor, similar to that which occurred in the existing Skyline Mine Permit Area, and rapidly/easily repaired by the lessee/operator as required under the Federal Mining Regulations, Utah Coal Rules, and Special Coal Lease Stipulations.

- Extension of the mine life would increase the length of time that mining related traffic volumes would occur on State Highways (Non-Significant Issue).

Existing traffic levels would be extended by up to 7 years. The traffic levels are well within design capabilities. Increased long-term traffic would be negligible, except for an unknown amount of increase related to increased recreation use. Traffic increases relative to anticipated coal exploration and construction of the vent shafts would be short-term ( 2 seasons) involving an increase of approximately 42 trips per day. Cumulative increases considering other activities and pipeline construction activities ( 50 trips per day for one season) would also be short-term and can be effectively mitigated by use of flaggers and signs. Some delays in traffic can be expected, but would be minimized by proper planning required to allow traffic passage.

- Mining-induced subsidence and seismicity could damage facilities at the Flat Canyon Campground (Significant Issue).

Under the Selected Alternative, the potential loss of use would be reduced to one summer season of 
use with additional time for repair. Special Coal Lease Stipulations would require the lessee/operator to monitor the facilities for damage and make prompt repairs such that the campground can be reopened as soon as possible. By closing the campground during active subsidence, safety concerns would be avoided. The cost of facility repairs would be borne by the lessee/operator and not the public.

- Mining-induced subsidence could damage recreation cabins and/or camp facilities and roads on adjacent private lands that are mined as a result of leasing the Flat Canyon Tract (Non-Significant Issue).

Project scoping indicated that the private landowners are generally in favor of mining even though some damages to surface facilities are expected from subsidence. Under the Federal Mining Regulations and Utah Coal Rules, the operator would be required to coordinate with surface landowners, repair damages, and compensate owners for any lost use.

\section{Surface and Ground Water}

- Prolonged and increased discharge of mine water into Eccles Creek could change water quality in Eccles Creek, other downstream drainages, and Scofield Reservoir. This could affect agricultural, domestic, and industrial water supplies as well as ecosystems (Non-Significant Issue).

The mine water discharge point is below the Forest Boundary in Eccles Creek. An increase in mine water discharge to Eccles Creek has already occurred over the last year. The increase was from less than $1,000 \mathrm{gpm}$ to approximately $15,000 \mathrm{gpm}$. As discussed in the FEIS stream morphology changes have already occurred and will continue for at least 2 more years regardless of my decision to consent to leasing of the Flat Canyon Tract.

The quality of discharge water has improved over the last year due to higher quantities of ground water encountered in Mine \#3, decreased dwell time in underground workings, and installation of a sand filtration system for Mine \#1 discharge. Quality of discharge water is expected to continue to improve over existing discharges.

A potential increase of 7,000 gpm of mine water discharge is possible as a result of mining the Flat Canyon Tract and adjacent private lands. If discharged to Eccles Creek, significant effects to the morphology of Eccles Creek and Mud Creek below the Forest boundary could occur. However, these effects can be mitigated by balancing discharge between Eccles Creek and a potential new discharge point in Electric Lake if a UPDES permit is issued Canyon Fuel by the Utah Division of Water Quality. In addition, Canyon Fuel is conducting a study to determine how much flow Eccles Creek and Mud Creek can accommodate without significant damages. Discharge above a potential threshold would be piped directly to Scofield Reservoir, bypassing the stream channels (personal communications with Chris Hansen, Canyon Fuel, December 20, 2001). The pipe could be buried under already disturbed areas such as the roadways minimizing additional surface disturbance and environmental effects. 
- A new mine water discharge point at the north end of Electric Lake would involve changing all or some of the discharge from Eccles Creek in the Price River Watershed to the Huntington Canyon Watershed. This could decrease flow in the Price River Watershed and increase flow in the Huntington Canyon Watershed (Significant Issue).

This issue was identified due to potential loss of pre-January 2001 flows of less than $1,000 \mathrm{gpm}$ to Scofield Reservoir if the discharge were shifted to Electric Lake. Due to the increased flows over the last year, level of concern regarding this issue has decreased. It is highly unlikely that all of the mine water discharge would be shifted from Eccles Creek to Electric Lake due to the high total volumes. It is predicted that an additional 7,000 gpm of mine water discharge could be required as a result of mining the Flat Canyon Tract. The current proposal involves decreasing flow to Eccles Creek from 15,000 gpm to $10,000 \mathrm{gpm}$ and discharge of approximately 12,000 gpm to Electric Lake. It appears likely that the State of Utah could issue a UPDES discharge permit to Canyon Fuel to discharge mine water to Electric Lake. This would allow the above scenario to occur. In addition, Canyon Fuel would have the ability to adjust discharge volumes to the two watersheds as needed to accommodate needs of the water users. Officials of both Water Districts have made it clear to the Forest Service and regulatory agencies that they are anxious to maximize flow to the respective reservoirs (Quarterly Meetings Hosted by the Manti-La Sal National Forest).

- Changing some or all of the mine water discharge from Eccles Creek to Electric Lake could change water quality in the receiving streams/water bodies (Significant Issue).

No increases in sediment are likely in Electric Lake because mine water and ground water discharge would be directly to the reservoir, bypassing Upper Huntington Creek. Adverse effects to Huntington Creek below the dam are not expected due to operation of the dam and controlled release to Huntington Creek based on precipitation cycles and seasonal runoff.

Due to the large quantity of ground water and increased discharge of ground water and mine water in Mine \#3, the quality of water discharged from the Skyline Mine has improved (EarthFax, Skyline Mine Discharge Evaluation, 2001). In addition, Canyon Fuel has increased their pumping capacities and have decreased dwell time of mine water in the mine workings causing additional increases in the quality of mine water (Chapter 4, Section 4.1.4). A sand filtration treatment system has been installed at the mine water discharge point in Eccles Canyon. All water except for discharge from abandoned workings in Mine \#3 is treated through this system (between 80 and $90 \%$ of water discharged). The remaining $10-20 \%$ is discharged from the Mine \#3 abandoned workings (personal communications with Chris Hansen, Canyon Fuel, December 21, 2001). By mixing these waters, quality requirements can be maintained. Based on recent analyses conducted by EarthFax (Skyline Mine Discharge Evaluation, 2001) and water quality data submitted to the Forest Service by Canyon Fuel for September, October, and November 2001 (project file) and mixing models prepared by EarthFax (December 17, 2001 Addendum to Skyline Mine Discharge Evaluation, project file), parameters of concern that include total dissolved solids, phenol, and phosphorous have decreased to low levels consistent with the receiving waters. Water quality meets State of Utah Beneficial Use Standards and water quality is generally consistent with quality of the receiving waters. Under 
normal operations, no adverse effects to water quality of the receiving streams and reservoirs are expected. Under requirements of a UPDES permit and Special Coal Lease Stipulations monitoring sufficient to detect increases in concentrations of selected parameters would be required and the lessee/operator would be required to treat discharge waters as needed to maintain water quality standards. Canyon Fuel proposes to monitor discharge water by automated methods and divert water that does not meet standards to the underground mine workings until standards can be met. Water from the two mine levels (Mines \#1 and \#3), new inflows, and mine water stored in the underground workings would be mixed during discharge to maintain water quality.

- Subsidence of perennial streams and the Boulger Dam/Reservoir could intercept flowing/impounded water and divert it underground, changing the hydrology (Significant Issue).

It has been determined in the FEIS, Section 4.1.4 and 4.1.5 that diversion of surface and ground water from subsidence is not likely and that any effects would be temporary and negligible under Alternative B'. The Selected Alternative decreases any potential even further by limiting the amount of subsidence that could occur beneath perennial streams.

- Subsidence could change the flow of springs and seeps, affecting the flow of springs and their receiving streams. This could affect agricultural, domestic, and industrial water supplies as well as ecosystems (Non-Significant Issue).

As discussed in the FEIS, Sections 4.1.4 and 4.1.5, the potential for loss of flow at springs is negligible under Alternative B' and therefore under the Selected Alternative. The potential for shifting of spring emergence locations is very low and confined to areas with shallow overburden. Overburden in the project area is 600 feet and greater, therefore the potential for this to occur is very remote. Under the Selected Alternative the amount of expected subsidence is decreased and the potential for spring water diversion is further reduced.

- Interception of ground water in underground mine workings and subsequent discharge to Eccles Creek (Existing NPDES Permit) could cause diversions of surface and ground water from the Huntington Canyon Drainage to the Price River Drainage. This could affect agricultural, domestic, and industrial water supplies as well as ecosystems (Significant Issue).

This issue was identified due to concerns of the local water users that ground water intercepted in the underground mine workings beneath the Huntington Canyon Watershed is being discharged and diverted to Eccles Creek in the Price River Watershed. As discussed in Section 4.1.5, the ground water encountered in the mines is ancient water that does not likely emerge as surface water to the Huntington Canyon Watershed. In addition, approximately 3,000 gpm of ground water is currently being discharged to Electric Lake from the James Canyon wells and approximately half of the water encountered in the mine could likely be discharged to Electric Lake, mitigating this concern.

- Equipment and materials spilled, used, and/or abandoned in underground mine workings could change ground water quality and any connected surface water sources. This could affect agricultural, domestic, and industrial water supplies as well as ecosystems (Non-Significant Issue).

As discussed in the FEIS, Sections 4.1.4 and 4.1.5 the potential for contamination of surface waters 
is very unlikely due to requirements that the lessee/operator obtain approval from the regulatory agencies to abandon equipment underground and that evidence must be provided to demonstrate that safety issues prevent removal or that there would be no connection between the ground water and surface waters. Operators are required to remove all fluids, batteries, etc. prior to abandoning any approved equipment underground, unless safety hazards prevent removal. In the Flat Canyon Tract and project area it is unlikely that there is any connection between ancient waters encountered in the coal seams and the surface environment because of the depth of the coal seams and related underground workings. Overburden depths range from 600 feet to well over 2,000 feet. The coal seams dip to the west and do not crop out west of the mine area.

\section{Vegetation}

- Subsidence and other mining-caused changes to surface and ground water could affect vegetation, especially riparian vegetation/wetlands (Significant Issue).

As discussed in the FEIS, Sections 4.1.4, 4.1.5, and 4.1.6 it is not likely that spring flow and associated wetlands would be affected. It is possible, but very unlikely that spring locations could shift due to subsidence and that the associated riparian vegetation communities would be affected. Under the Selected Alternative, the potential for this to occur would be further reduced due to limitation of subsidence to that expected for a single seam of full-extraction mining.

In regard to riparian communities associated with perennial streams, see Wildlife below.

- Construction of a pipeline and/or roads in or across riparian areas and/or wetlands could destroy vegetation and related habitat and increase downstream sediment (Non-Significant Issue).

Riparian areas would be avoided for construction of coal drilling pads and roads, but some stream crossings for access are anticipated. Streams would be crossed using bottomless pipe arches or bridges to minimize the disturbance to the stream channels, however it would be necessary to disturb some riparian areas adjacent to the streams. Perpendicular or near perpendicular crossings would be required to reduce disturbance. The disturbances would be temporary, lasting only one or two seasons. Reclamation of the disturbed area using riparian species would be required. Due to the small area (length of stream affected would be less than 30 feet for any individual road) relative to the adjacent stream channel lengths, re-vegetation with suitable species should be successful within 3-5 years.

\section{Wildlife}

- Exploration drilling, construction of mine vent holes, and reclamation activities could temporarily disrupt use of summer habitat by terrestrial species (Non-Significant Issue).

As discussed in the FEIS, Section 4.1.7 the construction activities associated with coal exploration drilling and construction of vent shafts are short-term. Avoidance would last only as long as the activities. Prompt reclamation following completion of operations would replace lost vegetation within 3-5 years. Less than one acre would be disturbed long-term for the two vent shafts. Since no fans will be installed, there would be no long-term noise that would displace use. 
- Any changes in stream gradient/morphology, water flow, and quality in perennial drainages, Boulger Reservoir, or riparian vegetation/wetlands could affect habitat for terrestrial and aquatic species. Includes changes in morphology due to flow changes and subsidence (Significant Issue).

The Forest Plan direction includes the following (pg. III-31, 02), "Give preferential consideration to riparian area dependent resources in cases of irresolvable resource conflicts" and (pg. III-22, 08) "Manage waters capable of supporting self-sustaining fish populations to provide for those populations". Plan standards include the following (pg. III-36, 01,d, (5)), "Coal leases may be denied or limited by special stipulations where operations would result in unacceptable or unmitigable impact on wildlife or fisheries" and "Proposed management activities which may cause unfavorable conditions in existing fisheries will include mitigation measures".

Under Alternatives B' and the Selected Alternative perennial streams would be subsided. Stream morphology changes to drainages with average gradients greater than $5 \%$ such as Swens and Little Swens Canyons would react to subsidence similar to Burnout Canyon where the subsidence study determined that effects were not significant. For drainages with less than $5 \%$ average gradient there is no direct empirical evidence regarding potential effects. The Selected Alternative would reduce the amount of anticipated subsidence from up to 13 feet for Alternative B' to less than 7 feet (NorWest, 2000, Technical Report on Geology, Mining, Subsidence, and Seismicity, Table 5.2). Maximum surface slope change anticipated for one seam of mining over a single abutment or single fire barrier would be less than 1.0\% (NorWest, 2000, Technical Report on Geology, Mining, Subsidence, and Seismicity, Tables 5.2 and 5.3, FEIS, Section 4.1.2, Table 4.1) as opposed to 3\% over stacked abutments with two overlapping seams of full-extraction mining.

The perennial stream reaches of greatest concern are Boulger Creek and Flat Canyon due to their relatively flat stream gradients of less than $3 \%$. In Flat Canyon the upper reaches above Flat Canyon Campground the stream gradient averages $0.93 \%$ and the maximum slope change is calculated at approximately $0.6 \%$. East of Flat Canyon Campground the stream gradient increases to approximately $3 \%$. In Boulger Creek the flattest gradient area is below the forks and above Boulger Reservoir where the average gradient is approximately $1.7 \%$. The channel below the reservoir steepens as it cuts through the glacial moraine. The forks have a steeper gradient ranging from $3.0 \%$ to $7.5 \%$. Considering the potential slope change, the anticipated subsidence should not cause a negative gradient over any extended stream reaches considering the average stream gradients. There is however potential for negative gradients to occur over short segments where the gradient is less than $1 \%$ as occurred in Burnout Creek (Utah Division of Oil, Gas and Mining, Letter to File Dated September 15, 2000, Subsidence in Burnout and James Canyons, Canyon Fuel Company, Skyline Mine, ACT $/ 007 / 005$, project file). As documented in this report, it was determined by the fisheries biologists in attendance that the pool had no adverse effects to aquatic habitat, the subsidence has had little or no effect on stream morphology, and that the creek is in good condition. The most likely scenario is that the percentage of pools in the streams would increase. Stream channel morphology could change as described in the FEIS, Section 4.1.7 and increased meandering is expected to a reduced extent. Since there would be only a single seam of full-extraction mining under the drainages and a single episode of subsidence, the stream channels would stabilize sooner than under Alternative B'. 
With required intensive monitoring of the channels and mitigations I believe that the effects to aquatic habitat can be mitigated to be consistent with Forest Plan standards for management of aquatic habitat. Attachment 2 contains a list of monitoring and mitigations to be incorporated as requirements for approval of the mine permit during the permit review and approval process. Special Coal Lease Stipulations \#3 and \#7 require baseline and operational monitoring sufficient to determine the progressive and final effects to the topographic surface, surface and ground water, and vegetation. The Federal Coal Mining Regulations (30 CFR 700 to end) and Utah Coal Rules provide authority to require mitigations needed to maintain land uses.

- Changes to flow in drainages and points of mine water discharge would affect aquatic wildlife species and habitat (Significant Issue).

The quality of water currently being discharged to Electric Lake from the James Canyon wells is approximately the same as the quality of water in upper Huntington Creek just above the reservoir. If a UPDES permit is issued by the Utah Division of Water Quality for discharge of mine water to James Canyon, monitoring would be required and limits to the quality of water that can be discharged would be set as requirements of the permit based on the quality of water in Upper Huntington Creek and/or Electric Lake. Discharge would be directly to Electric Lake so no effects would occur to Upper Huntington Creek. Discharge water must meet these quality standards. If monitoring shows exceedances, water would be discharged to mine sump areas, treated, or to Eccles Creek until water quality compliance is restored. Adverse effects to Electric Lake or Huntington Creek below the dam are not anticipated.

\section{$\underline{\text { Recreation }}$}

- Damage to recreation facilities and temporary closures (Boulger Dam/Reservoir, Flat Canyon Campground, Roads) could cause, displacement of recreation use to other areas, and/or loss of use during repairs/replacement and closure (Significant Issue).

The potential lost use of the Flat Canyon Campground would be reduced to approximately one season of use and time needed for repairs. In addition, the potential for lost use of Boulger Reservoir would be reduced to up to 7 years. This is acceptable from a recreation perspective since there would be an overall net benefit to recreation opportunities within a seven year period or less. Improvement of adjacent recreation facilities would be required of the lessee/operator such that they could accommodate displaced use and Boulger Reservoir would be improved resulting in improved quality of the facility and the recreation fishing experience.

- Subsidence could cause surface disruption and seismic events that could cause safety hazards and disrupt the recreation experience (Non-Significant Issue).

By closing Flat Canyon Campground and Boulger Reservoir over the short-term during active subsidence, the potential safety risks are eliminated. Prior to approval of mining by the regulatory authorities the lessee/operator is required to cooperate with private landowners regarding potential risks to facilities. The lessee/operator will be responsible for repairs and/or reimbursement of land and facility owners for damages and potential lost use of facilities during active subsidence and repairs. 
- Traffic and heavy equipment operation related to exploration drilling and drilling/construction of mine vent holes could temporarily disrupt dispersed recreation (Non-Significant Issue).

Traffic levels are expected to remain within design capabilities even with the extended period of mine traffic. Cumulative traffic levels associated with coal exploration, construction of the vent shafts, and pipeline construction are also expected to remain with design standards but could result in traffic delays at the SR-264, Monument Peak Road (FR50018). Required flaggers and warning signs would mitigate this short-term effect.

\section{Visual Quality}

- Equipment and ground disturbance related to drilling exploration holes, construction of ventilation shafts, and reclamation would temporarily (construction phase) decrease visual quality (NonSignificant Issue).

Visual quality objectives would be met and effects to visual quality are short-term.

- Ventilation shaft facilities, access roads, and any visible emissions (water vapor) would decrease visual quality for the life of the facilities (Non-Significant Issue).

Visual quality objectives for the disturbed area would be met. The access roads and portions of the vent shaft pads would be reclaimed and revegetated, minimizing visibility. Neither facility would be evident to traffic on SR-264.

\section{Transportation}

- Extension of the mine life would increase the length of time that mining-related traffic volumes would occur on State Highways (non-significant Issue).

Under the Selected Alternative existing traffic volumes related to mine operations would be extended for up to 7 years. Cumulative anticipated traffic levels during this time are expected to remain with design standards for SR-264 and SR-31. Short-term increases in traffic for projects such as coal exploration drilling, pipeline construction, and timber harvesting on private lands could cause short-term exceedances, but safety would be assured by requiring flaggers, warning signs, and restrictions on road use during high use periods such as holiday weekends and the opening weekends of the big game rifle hunting seasons.

\section{Cultural and Historic Resources}

- Construction of surface facilities and mining-induced subsidence could damage cultural resources.

No effects to cultural resources are anticipated. Potential effects to historic resources on private lands would be mitigated in accordance with the National Historic Preservation Act in consultation with the State Historical Preservation Office. 


\section{$\underline{\text { Paleontological Resources }}$}

- Underground mining, subsidence, and construction of surface facilities could damage paleontological resources.

No effects to significant paleontological resources are expected. Prior to conducting surface operations and disturbance surveys are required. If significant paleontological resources were discovered they would be avoided or recovered.

Paleontological resources in the coal seams and mine roof could be destroyed during the mining process but these resources typically have limited scientific value. In the Federal Regulations contained in 36 CFR 261.2 pertaining to prohibitions on uses of National Forest System lands, paleontological resources are defined as "any evidence of fossilized remains of multicellular invertebrate and vertebrate animals and multicellular plants, including imprints thereof. Organic remains primarily collected for use as fuel such as coal and oil are Paleontological Resources, but are excluded from prohibitions under the rule". Therefore, fossils contained in coal seams and mined in the recovery of coal reserves are not protected under the rule.

\section{$\underline{\text { Socio-economics }}$}

- Leasing of the tract would extend the life of the Skyline Mine, provide an important energy resource, and result in social and economic benefits. If the mine closes, there could be a loss of jobs and socioeconomic benefits (Significant Issue).

The mine life could be extended by up to 7 years. The 220 jobs at the Skyline Mine and undetermined number of support service jobs related to Skyline Mine would be extended for this period of time.

The recoverable reserves are estimated at approximately 28 million tons at a total value of approximately $\$ 476$ million. Royalties would be approximately $\$ 38$ million. It is likely the Canyon Fuel will bid on the tract and meet fair market value. An undetermined amount of bonus bid money would be received in addition to royalties.

\section{PUBLIC INVOLVEMENT}

The Forest Service and BLM initiated scoping (30 day comment period) by publication of a Notice of Intent to Prepare an EIS in the Federal Register on March 17, 2000. A legal notice informing the public of the intent to evaluate the Flat Canyon Coal Lease Tract, prepare an EIS, and requesting issues and concerns, were published in the Sun Advocate Newspaper (publication of record) and the Emery County Progress (supplemental publication) on March 14, 2000. The legal notice was also published in the $M t$. Pleasant Pyramid on March 15, 2000. A letter was sent to 100 agencies, individuals, and organizations on March 13, 2000 briefly explaining the proposed action and requesting comments regarding issues and concerns. The comment period ended at the close of business on April 18, 2000. The project was listed on the Forest Internet website and Quarterly Schedule of Proposed Actions. In addition, the proposed 
project was explained to local resource user organizations at the quarterly water users meetings and Emery County Public Lands Council meetings.

A letter was sent to the owners of private lands within and adjacent to the project area on October 30, 2000 informing them of the project and requesting comments followed by phone calls. Only one letter of response was received from the LDS Church asking for some additional information that was provided by telephone. The conversations with landowners divulged that they generally wanted to see the Federal and private lands mined. Some were concerned about potential damages to buildings from subsidence but felt that any necessary repairs would be made by the mining operator. At least two of the landowners were concerned about potential effects to springs within and adjacent to their property. One landowner was concerned about potential lowering of the private roads that cross Flat Canyon due to subsidence and that it would be difficult to relocate them because of the wetlands issue.

Nine letters and two phone calls were received in response to scoping. The Interdisciplinary Team (IDT) evaluated comments and identified the proposed issues based on the comments and concerns identified by participating agencies. The issues were approved by the agency responsible officials on June 8, 2000.

The Draft EIS was released for a 45-day public review in May 2001. The 45-day review period started on May 19, 2001, the day after the Environmental Protection Agency published the Notice of Availability in the Federal Register (Vol. 66, No. 97/Friday, May 18, 2001/Notices). The comment period ended at close of business on the 45th day, July 2, 2001. On May 8, 2001, copies of the DEIS were sent to individuals, agencies, and companies who responded to scoping, all agencies with direct interest or authority regarding the proposed action, and anyone who requested a copy for review prior to the date of the letter. Additional copies were provided to those requesting a copy for review after the letter was sent. Notices of Availability were published in the Sun Advocate. Newspaper (publication of record) and the Emery County Progress (supplemental publication) on May 15, 2001. The Notice of Availability was also published in the Mt. Pleasant Pyramid, on May 16, 2001. Approximately 120 copies of the DEIS were distributed as described above. Comments and responses regarding the adequacy of the DEIS are contained in Chapter 5 of the FEIS.

The FEIS and this ROD were sent to individuals and organizations listed in Attachment 4. Additional copies will be made available upon request.

\section{ALTERNATIVES CONSIDERED}

\section{A. Alternatives Considered in Detail, But Not Selected}

Alternatives were developed to address the significant issues associated with the project and to meet the requirements of NEPA. The alternatives addressed cover both ends of the spectrum regarding the possibilities for leasing/mining. Alternative A (No Action) presents the effects of not leasing the Tract. Alternative $B$, at the other end of the spectrum is a leasing scenario with no special stipulations, representing the full-mining scenario where mining would be conducted to maximize efficiency and coal recovery without specific measures to protect surface resources. Alternative B' (B Prime) is a derivative of $B$ that would result in the same mining scenario without restrictions to prevent subsidence of sensitive 
resource areas, but differs in that it includes Special Coal Lease Stipulations (SCLS) that would require specific monitoring and mitigations in the event that specific effects occur. Alternative $\mathrm{C}$ lies in between, representing a leasing scenario where SCLSs would be included in the lease and subsidence of sensitive resources and facilities/structures would not be allowed regardless of the potential level of effects to them. To provide information to the public and decision makers, so that combinations of these alternatives can be considered, each of the sensitive resources and structures/facilities are addressed individually in the analysis. All of the following alternatives were considered in the EIS.

ALTERNATIVE A, NO ACTION - The no action alternative provides a baseline for estimating the effects of the action alternatives. Under this alternative the lease tract would not be offered for leasing and there would be no mining.

\section{ALTERNATIVE B, OFFER THE TRACT FOR LEASING AS DELINEATED/WITHOUT} SPECIAL LEASE STIPULATIONS - Under this alternative the tract would be offered for competitive leasing, as delineated by the Tract Delineation Team, with BLM standard lease terms and conditions only, as displayed in Appendix B. No special coal lease stipulations would be included in the lease to be offered. Longwall (full-extraction) mining would be allowed throughout the tract resulting in subsidence of perennial drainages, Boulger Dam and Reservoir, Flat Canyon Campground, State Route 264 (other than along Upper Huntington Creek), and structures on private lands within the project area. It would be analyzed as the basis for comparison with other action alternatives that would include special stipulations needed to protect non-mineral resources and uses.

This alternative does not specifically meet Forest Plan requirements because it does not include any of the 17 Special Coal Lease Stipulations (SCLSs) prescribed for coal leases on National Forest System lands, on an as needed basis (Forest Plan, 1986, as amended, General Direction, Page III-35 and Appendix B, Pages B-2 through B-4). Special stipulations were not included for the purpose of disclosing the effects of leasing without special stipulations.

\section{ALTERNATIVE B' (B PRIME), OFFER THE TRACT AS DELINEATED WITH SPECIAL COAL LEASE STIPULATIONS BUT WITHOUT RESTRICTIONS ON MINING THAT WOULD CAUSE SUBSIDENCE OF SENSITIVE SURFACE RESOURCES - Under this} alternative, the tract would be offered for competitive leasing, as delineated, with BLM standard lease terms and conditions and special stipulations to protect non-mineral resources and uses. Special coal lease stipulations for this alternative are included in Appendix C. The mining scenario would be the same as Alternative $B$, without restrictions on subsiding sensitive resources, but would include lease stipulations that require mitigation of effects. In some cases, the opportunity exists to include similar requirements in the mine permit during the mining plan review and permitting process. For the purposes if this analysis, it is assumed that similar measures not specifically required by law or regulation would not be applied.

This Alternative B' would be consistent with Forest Plan direction (Forest Plan, 1986, as amended, General Direction, Page III-35 and Appendix B, Pages B-2 through B-4).

ALTERNATIVE C, OFFER THE TRACT FOR LEASING AS DELINEATED/WITH SPECIAL LEASE STIPULATIONS (Do Not Allow Subsidence of Perennial Drainages, Boulger Dam and Reservoir, or Flat Canyon Campground) - Under this alternative, the tract would be offered for 
competitive leasing, as delineated, with BLM standard lease terms and conditions and special stipulations to protect non-mineral resources and uses. Special coal lease stipulations for this alternative are included in Appendix C. Subsidence of perennial drainages, Boulger Dam and Reservoir, State Route 264, and Flat Canyon Campground would not be allowed. Subsidence of structures on private lands within the project area could occur, if the lessee/operator obtains permission from private coal estate owner(s), under agreement with the private surface estate owner(s). This alternative would be consistent with Forest Plan direction (Forest Plan, 1986, as amended, General Direction, Page III-35 and Appendix B, Pages B-2 through B-4).

OTHER ACTION ALTERNATIVES - Alternatives B and C define the least and most restrictive action alternatives regarding leasing/mining and resource protection. Other alternatives were considered in the decisions, as needed, to address significant social and environmental issues or opportunities. In formulating other alternatives for consideration in the EIS, the Forest Service and BLM looked at the tract boundary and potential restrictions on underground mining and surface occupancy needed to protect non-mineral resources and uses. Sensitive resource areas were specifically and individually

evaluated under Alternatives $\mathrm{B}$ and $\mathrm{C}$ such that the effects can be adequately considered and disclosed if the decisions involve a combination of the evaluated alternatives. The Selected Alternative, which is essentially a combination of Alternatives $\mathrm{B}^{\prime}$ and $\mathrm{C}$, was based on this concept.

\section{Findings Required by Other Laws and Regulations}

After consideration of the discussion of environmental consequences (FEIS, Chapter Four), I have determined that the Selected Alternative (a combination of Alternatives B' and C with modifications) is consistent with other laws and regulations, as outlined in the FEIS.

\section{A. Consistency with Forest Plan Direction}

Regulations and Requirements - All resource plans are to be consistent with the Forest Plan [16 U.S.C. 1604 (i)]. The Forest Plan guides all natural resource management activities [36 Code of Federal Regulations (CFR) 219.1 (b)]. All administrative activities affecting the National Forest must be based on the Forest Plan [36 CFR 219.10(e)].

The Forest Plan was approved on November 5, 1986. The FEIS for the South Manti Timber Salvage tiers to the Forest Plan. The Forest Plan provides for the overall guidance for management activities by specifying goals and objectives, desired future conditions, management direction, and standards and guidelines.

The features of the Selected Alternative have been evaluated for consistency with the Forest Plan and I have determined that the Selected Alternative is in compliance with the Forest Plan. No Forest Plan amendments will be needed to implement this project.

\section{B. Consistency with the National Forest Management Act}

The Selected Alternative is consistent with the National Forest Management Act (NFMA) of 1976 in meeting the management requirements detailed in implementing regulations of 36 CFR 219.27. The 
Special Coal Lease Stipulations provide for protection of soil, water, air, wildlife, fishery resources, and other multiple uses.

\section{Consistency with Other Laws and Regulations}

Clean Water Act - The Clean Water Act requires each state to implement its own water quality standards. The State of Utah's Water Quality Antidegradation Policy requires maintenance of water quality to protect existing instream beneficial uses on streams designated as Category 1 High Quality Waters. All surface waters geographically located within the outer boundaries of the Manti-La Sal National Forest, whether on private or public lands are designated as High Quality Waters (Category 1). Water quality is to be maintained with little or no degradation. New point source discharges are prohibited; nonpoint sources will be controlled to the extent feasible through implementation of Best Management Practices (BMP's) or regulatory programs (Utah Division of Water Quality 1997). The State of Utah and the Forest Service have agreed through a 1993 Memorandum of Understanding to use Forest Plan Standards and Guidelines, and the Forest Service Handbook (FSH) 2509.22 Soil and Water Conservation Practices (SWCP's) as the BMP's. The use of SWCP's as BMP's meet the water quality protection elements of Utah's Nonpoint Source Management Plan.

The Beneficial uses and high quality water in the streams in the project area would be maintained during and following project implementation through proper implementation of BMP's and Project Design Features.

On November 30, 2001 the Utah Water Quality Board changed the designation of Electric Lake from High Quality Water - Category 1 (no new point source discharges allowed) to High Quality Water Category 2 (new discharge allowed if there is no degradation of water quality). This was in response to a request by Canyon Fuel for this reclassification in anticipation of obtaining the Flat Canyon Tract and their proposal to discharge a portion of water entering the mine to Electric Lake.

Executive Order 11990 of May, 1977 - This requires the Forest Service to take action to minimize destruction, loss, or degradation of wetlands and to preserve and enhance the natural and beneficial values of wetlands. In compliance with this order, Forest Service direction requires that an analysis be completed to determine whether adverse impacts would result.

Wetlands in the project area are associated with perennial streams and their headwaters. The Selected Alternative would be compliant with Executive Order 11990. Some changes to stream morphology are anticipated from subsidence. Detailed monitoring would be conducted and the lessee/operator will be required to mitigate potential effects. No loss of flow contributing to these areas is anticipated.

Executive Order 11988 of May, 1997 - This order requires the Forest Service to provide leadership and to take action to (1) minimize adverse impacts associated with occupancy and modification of floodplains and reduce risks of flood loss, (2) minimize impacts of floods on human safety, health, and welfare, and (3) restore and preserve the natural and beneficial values served by flood plains. In compliance with this order, the Forest Service requires an analysis be completed to determine the significance of proposed actions in terms of flood plains. 
Some changes to stream morphology are anticipated from subsidence. Detailed monitoring would be conducted and the lessee/operator will be required to mitigate potential effects. No loss of flow contributing to these areas is anticipated. Therefore, the Selected Alternative will be in compliance with Executive Order 11988.

Endangered Species Act of 1973, as Amended - Based upon the effects analysis in Chapter Four, the Biological Assessment (project file) and concurrence with the US Fish and Wildlife Service, it has been determined that there would be no adverse effects to populations of threatened, endangered, or proposed wildlife, fish, or plant species relative to the Selected Alternative.

Migratory Bird Treat Act of 1918 - The Selected Alternative will retain viable populations of native species.

American Antiquities Act of 1906 and Historic Preservation Act of 1966 - Based upon the effects analysis in Chapter Four and the Memorandum of Understanding with the Utah State Historic Preservation, it has been determined that there will be no measurable effects to any Historic Properties relative to the Selected Alternative. Any cultural properties discovered during project activities will be avoided, protected, or mitigated (see Special Coal Lease Stipulations, Attachment 1 and the FEIS, Unsuitability Analysis, Appendix F).

Clean Air Act, as Amended in 1977 - Based upon the effects analysis in Chapter Four, it has been determined that there will be no measurable effects to air quality and that all alternatives would comply with State air quality requirements and the Clean Air Act.

Civil Rights - Based upon comments received during scoping and the comment period for the DEIS, no conflicts have been identified with other Federal, State, or local agencies or with Native Americans, other minorities, women, or civil rights of any United States citizen.

Secretary of Agriculture Memorandum, 1827 - The Selected Alternative is in conformance for prime farmland, rangeland, and forestland.

Energy - The Selected Alternative would not have unusual energy requirements and would meet the intent of the Presidents Energy Policy.

Executive Order 12898, "Federal Actions to Address Environmental Justice in Minority Populations and Low-Income Populations." - This order requires the Forest Service to make achieving environmental justice part of its mission by identifying and addressing as appropriate, disproportionately high and adverse health effects, of its programs, policies, and activities on minority populations and low-income populations in the United States and territorial possessions. In compliance with this executive order, the Manti-La Sal National Forest, through intensive scoping and public involvement attempted to identify interested and affected parties, including minority and low-income populations for this project. The Forest defined a range of alternatives to be evaluated and analyzed the consequences of the alternatives on the quality of human environment. A comment period was held for 45 days for the DEIS following the U.S. Environmental Protection Agency's publication of the Notice of Availability in the Federal Register. 
The land described in this analysis is managed by the USDA Forest Service as the Manti-La Sal National Forest. The adjacent private lands in the project areas are managed by the private landowners. Consultation with the landowners has been conducted. The decision for this document will not amend or preclude any existing private or treaty rights in the project area. No minority or low-income populations were identified during the pubic involvement within communities near or immediately surrounding the South Manti project area.

\section{ENVIRONMENTALLY PREFERRED ALTERNATIVE}

Regulations implementing the National Environmental Policy Act (NEPA) require agencies to specify "the alternative or alternatives which were considered to be environmentally preferable" [40 CFR 1505.2(b)]. Forest Service policy further defines the "environmentally preferable alternative" as "an alternative that meets the goals of Section 101 of the NEPA." (FSH 1909.15). Section 101 of the NEPA describes national environmental policy, calling on federal, state, and local governments and the public to "create and maintain conditions under which man and nature can exist in productive harmony." Section 101 further defines this policy in six broad goals, to:

(1) fulfill the responsibilities of each generation as trustee of the environment for succeeding generations;

(2) assure for all Americans safe, healthful, productive, and esthetically and culturally pleasing surroundings;

(3) attain the widest range of beneficial uses of the environment without degradation, risk to health, or safety, or other undesirable and unintended consequences;

(4) preserve important historic, cultural, and natural aspects of our national heritage, and maintain, wherever possible, an environment which supports diversity and a variety of individual choice;

(5) achieve a balance between population and resource use which permit high standards of living and a wide sharing of life's amenities; and

(6) enhance the quality of renewable resources and approach the maximum attainable recycling of depletable resources.

From the perspective of causing the least amount of change to the natural environment, Alternative A (No Action) would be preferable. Considering a combination of all of the items described above, I believe that Alternative $C$ best meets the goals of Section 101, and is therefore the environmentally preferable alternative for this proposed federal action. However, Alternative $\mathrm{C}$ has a high potential to render the coal reserves not mineable from an economic perspective and the related adverse socioeconomic effects would be significant. In addition, it does not provide the best balance between socioeconomic benefits and effects to the natural environment. Therefore, I did not select it. 


\section{IMPLEMENTATION DATE}

This project cannot be implemented until 15 days after the resolution of any appeal. If no appeal is received, the project may be implemented five days after the end of the appeal period.

\section{ADMINISTRATIVE REVIEW}

This decision is subject to appeal pursuant to 36 CFR 215.7. Any written appeal must be postmarked or received by the Appeal Deciding Officer within 45 days of the publication of a legal notice in the Sun Advocate. The Appeal Deciding Officer is: Regional Forester, Intermountain Region, 324-25th Street, Ogden, UT 84401. Appeals must meet the content requirements of 36 CFR 215.14.

This decision is subject to appeal pursuant to 36 CFR 251.82. Notice of appeal must be postmarked or received by the Appeal Reviewing Officer within 45 days of the date of this decision. A notice of appeal, including the reasons for appeal, must be filed with the Regional Forester, Intermountain Region, Federal Building, 324-25th Street, Ogden, Utah 84401. A copy of the notice of appeal must be filed simultaneously with Elaine J. Zieroth, Forest Supervisor, 599 West Price River Drive, Price, Utah 84501. Appeals must meet the content requirements of 36 CFR 251.90.

For further information, contact Carter Reed or Aaron Howe, Manti-La Sal National Forest, 599 West Price River Drive, Price, Utah 84501, or phone (435) 637-2817.
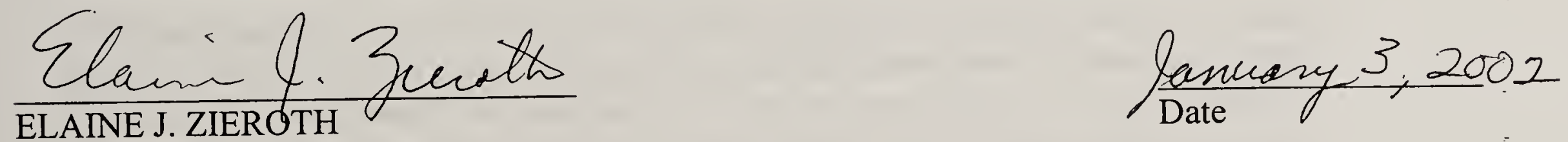

Forest Supervisor 
C 


\section{ATTACHMENT 1 \\ SPECIAL COAL LEASE STIPULATIONS}

Federal Regulations 43 CFR 3400 pertaining to Coal Management make provisions for the Surface Management Agency, the surface of which is under the jurisdiction of any Federal agency other than the Department of Interior, to consent to leasing and to prescribe conditions to insure the use and protection of the lands. All or part of this lease contain lands the surface of which are managed by the United States Department of Agriculture, Forest Service, Manti-La Sal National Forest.

The following stipulations pertain to the Lessee responsibility for mining operations on the lease area and on adjacent areas as may be specifically designated on National Forest System lands.

\section{Stipulation \#1}

Before undertaking activities that may disturb the surface of previously undisturbed leased lands, the Lessee may be required to conduct a cultural resource inventory and a paleontological appraisal of the areas to be disturbed. These studies shall be conducted by qualified professional cultural resource specialists or qualified paleontologists, as appropriate, and a report prepared itemizing the findings. A plan will then be submitted making recommendations for the protection of, or measures to be taken to mitigate impacts for identified cultural or paleontological resources.

If cultural resources or paleontological remains (fossils) of significant scientific interest are discovered during operations under this lease, the Lessee prior to disturbance shall immediately bring them to the attention of the appropriate authority. Paleontological remains of significant scientific interest do not include leaves, ferns or dinosaur tracks commonly encountered during underground mining operations.

The cost of conducting the inventory, preparing reports, and carrying out mitigating measures shall be borne by the Lessee.

\section{Stipulation \#2}

If there is reason to believe that Threatened or Endangered (T\&E) species of plants or animals, or migratory bird species of high Federal interest occur in the area, the Lessee shall be required to conduct an intensive field inventory of the area to be disturbed and/or impacted. The inventory shall be conducted by a qualified specialist and a report of findings will be prepared. A plan will be prepared making recommendations for the protection of these species or action necessary to mitigate the disturbance. 
The cost of conducting the inventory, preparing reports and carrying out mitigating measures shall be borne by the Lessee.

\section{Stipulation \#3}

The Lessee shall be required to perform a study to secure adequate baseline data to quantify the existing surface resources on and adjacent to the lease area. Existing data may be used if such data are adequate for the intended purposes. The study shall be adequate to locate, quantify, and demonstrate the interrelationship of the geology, topography, surface and ground water hydrology, vegetation and wildlife. Baseline data will be established so that future programs of observation can be incorporated at regular intervals for comparison.

\section{Stipulation \#4}

Powerlines used in conjunction with the mining of coal from this lease shall be constructed so as to provide adequate protection for raptors and other large birds. When feasible, powerlines will be located at least 100 yards from public roads.

\section{Stipulation \#5}

The limited area available for mine facilities at the coal outcrop, steep topography, adverse winter weather, and physical limitations on the size and design of access roads, are factors that will determine the ultimate size of the surface area utilized for the mine. A site-specific environmental analysis will be prepared for each new mine site development and for major improvements to existing developments to examine alternatives and mitigate conflicts.

\section{Stipulation \#6}

Consideration will be given to site selection to reduce adverse visual impacts. Where alternative sites are available, and each alternative is technically feasible, the alternative involving the least damage to the scenery and other resources shall be selected.

Permanent structures and facilities will be designed, and screening techniques employed to reduce visual impacts and, where possible, achieve a final landscape compatible with the natural surroundings. The creation of unusual, objectionable, or unnatural landforms and vegetative landscape features will be avoided.

\section{Stipulation \#7}

The Lessee shall be required to establish a monitoring system to locate, measure and quantify the progressive and final effects of underground mining activities on the topographic surface, underground and surface hydrology and vegetation. The monitoring system shall utilize techniques that will provide a continuing record of change over time and an analytical method for location and measurement of a number of points over the lease area. The monitoring shall incorporate and be an extension of the baseline data.

\section{Stipulation \#8}

The Lessee shall provide for the suppression and control of fugitive dust on haul roads and at coal handling and storage facilities. On Forest Development Roads (FDR), Lessees may perform their share of road maintenance by a commensurate share 
agreement if a significant degree of traffic is generated that is not related to their activities.

\section{Stipulation \#9}

Except at specifically approved locations, underground mining operations shall be conducted in such a manner so as to prevent surface subsidence that would: (1) cause the creation of hazardous conditions such as potential escarpment failure and landslides, (2) cause damage to existing surface structures, and (3) damage or alter the flow of perennial streams. The Lessee shall provide specific measures for the protection of escarpments, and determine corrective measures to assure that hazardous conditions are not created.

Limited subsidence zones consisting of perennial streams in the lease, Boulger Reservoir/Dam, SR-264, and Flat Canyon Campground are specifically approved for subsidence resulting from a single-seam of full-extraction mining. The limitedsubsidence zones, where subsidence from a second overlapping seam of full-extraction mining is not approved, will be determined based on the typical angle-of-draw for past operations in the Skyline Mine Permit Area (23 degrees). "Angle-of-draw" is defined in the FEIS (pg. 4-7). The angle-of-draw will be applied to perennial stream buffer zones that include the natural floodplain and alluvium in perennial drainages, bounded by the first major slope break in the associated canyons. For structures, it will be applied to an area delineated by a 50 -foot radius or distance from the major structures that could sustain damage.

\section{Stipulation \#10}

In-order to avoid surface disturbance on steep canyon slopes and to preclude the need for surface access, all surface breakouts for ventilation tunnels shall be constructed from inside the mine, except at specific approved locations.

\section{Stipulation \#11}

If removal of timber is required for clearing of construction sites, etc., such timber shall be removed in accordance with the regulations of the surface management agency.

\section{Stipulation \#12}

The coal contained within, and authorized for mining under this lease shall be extracted only by underground mining methods.

\section{Stipulation \#13}

Existing Forest Service owned or permitted surface improvements will need to be protected, restored, or replaced to provide for the continuance of current land uses.

\section{Stipulation \#14}

In order to protect big-game wintering areas, elk calving and deer fawning areas, sagegrouse strutting areas, and other key wildlife habitat and/or activities, specific surface uses outside the mine development area may be curtailed during specified periods of the year. 


\section{Stipulation \#15}

Support facilities, structures, equipment, and similar developments will be removed from the lease area within two years after the final termination of use of such facilities. This provision shall apply unless the requirement of Section 10 of the lease form is applicable. Disturbed areas and those areas previously occupied by such facilities will be stabilized and rehabilitated, drainages re-established, and the areas returned to a premining land use.

\section{Stipulation \#16}

The Lessee, at the conclusion of the mining operation, or at other times as surface disturbance related to mining may occur, will replace all damaged, disturbed or displaced corner monuments (section corners, $1 / 4$ corners, etc.), their accessories and appendages (witness trees, bearing trees, etc.), or restore them to their original condition and location, or at other locations that meet the requirements of the rectangular surveying system. This work shall be conducted at the expense of the Lessee, by a professional land surveyor registered in the State of Utah, and to the standards and guidelines found in the Manual of Surveying Instructions, United States Department of the Interior.

\section{Stipulation \#17}

The Lessees, at their expense, will be responsible to replace any surface and/or developed groundwater sources identified for protection, that may be lost or adversely affected by mining operations, with water from an alternate source in sufficient quantity and quality to maintain existing riparian habitat, fishery habitat, livestock and wildlife use, or other land uses (authorized by 36 CFR 251). 


\title{
Stipulation \#18
}

\section{STIPULATION FOR LANDS OF THE NATIONAL FOREST SYSTEM UNDER JURISDICTION OF THE DEPARTMENT OF AGRICULTURE}

The licensee/permittee/lessee must comply with all the rules and regulations of the Secretary of Agriculture set forth at Title 36, Chapter II, of the Code of Federal Regulations governing the use and management of the National Forest System (NFS) when not inconsistent with the rights granted by the Secretary of the Interior in the license/permit/lease. The Secretary of Agriculture's rules and regulations must be complied with for (1) all use and occupancy of the NFS prior to approval of a permit/operation plan by the Secretary of Interior, (2) uses of all existing improvements, such as Forest Development Roads, within and outside the area licensed, permitted or leased by the Secretary of Interior, and (3) use and occupancy of the NFS not authorized by a permit/operating plan approved by the Secretary of the Interior.

All matters related to this stipulation are to be addressed to:

Forest Supervisor

Manti-La Sal National Forest

599 West Price River Drive

Price, Utah 84501

Telephone Number: 801-637-2817

who is the authorized representative of the Secretary of Agriculture

\author{
Signature \\ Licensee/Permittee/Lessee
}

\section{Stipulation \#19}

\section{ABANDONMENT OF EQUIPMENT:}

The lessee/operator is responsible for compliance and reporting regarding toxic and hazardous material and substances under Federal Law and all associated amendments and regulations for the handling of such materials on the land surface and in underground mine workings.

The lessee/operator must remove mine equipment and materials not needed for continued operations, roof support and mine safety from underground workings prior to abandonment of mine sections. Exceptions can be approved by the Authorized Officer (BLM) in consultation with the surface management agency. Any on-site disposal of non-coal waste must comply with 30CFR $\S 817.89$ and must be approved by the 
regulatory authority responsible for the enforcement of the Surface Mining Control and Reclamation Act (30 U.S.C. 1201, et seq.). Creation of a situation that would prevent removal of such material and equipment by retreat or abandonment of mine sections, without prior authorization would be considered noncompliance with lease terms and conditions and subject to appropriate penalties under the lease.

All safe and accessible areas shall be inspected prior to being sealed. The lessee shall notify the Authorized Officer in writing 30 days prior to the sealing of any areas in the mine and state the reason for closure. Prior to seals being put into place, the lessee shall inspect the area and certify through documentation any equipment/machinery, hazardous substances, and used oil that is intended to be left underground. The Authorized Officer may participate in this inspection. The purpose of this inspection will be: (1) to provide documentation for compliance with 42 U.S.C. 9620 section 120 (h) and State Management Rule R-315-15, and to assure that certification will be meaningful at the time of lease relinquishment, (2) to document the inspection with a mine map showing location of equipment/machinery (model, type of fluid, amount remaining, batteries, etc.) that is proposed to be left underground. In addition, these items will be photographed at the lessee's expense and shall be submitted to the Authorized Officer as part of the certification.

\section{WASTE CERTIFICATION:}

The lessee shall provide on a yearly basis and prior to lease relinquishment, certification to the lessor that, based upon a complete search of all the operator's records for the mine and upon their knowledge of past operations, there has been no hazardous substances defined as per (40 CFR 302.4) or used oil as per Utah State Management Rule R-315-15, deposited within the lease, either on the surface or underground, or that all remedial action necessary has been taken to protect human health and the environment with respect to any such substances remaining on the property. The back-up documentation to be provided shall be described by the lessor prior to the first certification and shall include all documentation applicable to the Emergency Planning and Community Rightto-know Act (EPCRA, Public Law 99-499), Title III of the Superfund Amendments and Reauthorization Act of 1986 or equivalent.

\section{Stipulation \#20}

Notwithstanding the approval of a resource recovery and protection plan by the BLM, lessor reserves the right to seek damages against the operator/lessee in the event (1) the operator/lessee fails to achieve maximum economic recovery [as defined at 43 CFR $\S$ $3480.0-5(21]$ of the recoverable coal reserves or (2) the operator/lessee is determined to have caused a wasting of recoverable coal reserves. Damages shall be measured on the basis of the royalty that would have been payable on the wasted or unrecovered coal.

The parties recognize that under an approved $\mathrm{R} 2 \mathrm{P} 2$, conditions may require a modification by the operator/lessee of that plan. In the event a coal bed or portion thereof is not to be mined or is rendered unminable by the operation, the operator shall submit appropriate justification to obtain approval by the Authorized Officer to leave such reserves unmined. Upon approval by the Authorized Officer, such coal beds or portions 
thereof shall not be subject to damages as described above. Further, nothing in this section shall prevent the operator/lessee from exercising its right to relinquish all or portion of the lease as authorized by statute and regulation.

In the event the Authorized Officer determines that the R2P2 as approved will not attain MER as the result of changed conditions, the Authorized Officer will give proper notice to the operator/lessee as required under applicable regulations. The Authorized Officer will order a modification if necessary, identifying additional reserves to be mined in order to attain MER. Upon a final administrative or judicial ruling upholding such an ordered modification, any reserves left unmined (wasted) under that plan will be subject to damages as described in the first paragraph under this section.

Subject to the right to appeal hereinafter set forth, payment of the value of the royalty on such unmined recoverable coal reserves shall become due and payable upon determination by the Authorized Officer that the coal reserves have been rendered unminable or at such time that the lessee has demonstrated an unwillingness to extract the coal.

The BLM may enforce this provision either by issuing a written decision requiring payment of the MMS demand for such royalties, or by issuing a notice of noncompliance. A decision or notice of non-compliance issued by the lessor that payment is due under this stipulation is appealable as allowed by law. 


\section{ATTACHMENT 2 \\ MONITORING AND MITIGATION MEASURES \\ TO BE \\ INCORPORATED AS APPROPRIATE \\ AS \\ CONDITIONS OF CONSENT TO MINE PERMIT ISSUANCE \\ FOR \\ MINING IN THE FLAT CANYON TRACT}

\section{Monitoring}

Forest Service Stipulations \#3 and \#7 require establishment of a scientific baseline against which to monitor possible effects of subsidence. Note that establishing a baseline is not a one-year enterprise; typically three to five years is the minimum and five to seven is frequently needed to reliably assess human-induced change beyond natural variability. A baseline inventory and subsequent monitoring should include the following:

- Valley and stream morphology - annual topographically controlled, low-elevation aerial photography plus stream hydraulic surveys (longitudinal profile, crosssections, channel bed/bank material)

- Precipitation - continuously operated recording gages

- Valley groundwater levels, stream and spring discharge quantity - continuously operated recording gages

- Valley groundwater, stream, and spring chemistry - periodic grab samples

- Valley groundwater, stream, and spring temperature - continuously operated data recorders at selected sites

- Fish habitat - annual detailed mapping of habitat units

- Fish and macroinvertebrate populations - annual population sampling in representative sections of each stream reach and Electric Lake

- Wetlands (flora) - mapping and characterization, including pollen columns at selected sites, plus detailed inventory and monitoring of plant species and distribution in wetlands associated with springs and seeps

- Wetlands (fauna) - periodic surveys for dependent species, including amphibians and aquatic organisms 


\section{Mitigation/Rehabilitation}

The information developed from the baseline inventories will establish the range of "normal" conditions. As appropriate this information will be supplemented by research findings or off-site information. Changes identified through monitoring which exceed this "normal" range will require remedial/restorative actions by the mining company.

\section{$\underline{\text { Surface Water }}$}

Enrichment of Electric Lake/change in trophic state from mine water discharge Installation and operation of aerators at one or more locations. Aeration is generally effective in offsetting eutrophication effects.

Thinning of ice on Electric Lake around mine discharge point - Installation of warning signs. The effectiveness of warning signs for this situation is unknown.

\section{$\underline{\text { Vegetation }}$}

Loss of streamside riparian vegetation due to stream channel adjustments - See the Aquatic Wildlife section.

\section{$\underline{\text { Aquatic Wildlife }}$}

Subsidence-caused pooling and subsequent breaching, lateral migration of stream channel, stream channel entrenchment, and sediment accumulation - These and associated secondary effects like loss of streamside vegetation and aquatic habitat features are usually mitigated with an integrated package of treatments. Put another way, individual areas may be temporarily stabilized, but long-term restoration will be more effective if combined with other treatments in a stream reach. Treatments, in varying combinations, may include the following:

- Construction and vegetation of realigned stream channel segments;

- Construction of one or more sediment basins at the breached Boulger Reservoir site;

- Temporary breaching of subsidence-caused pools;

- Construction of in-channel grade controls;

- Structures to recreate specific habitat features, such as wetted secondary channels or pool with effective flow-through velocities;

- Riparian plantings to stabilize stream banks; or

- Placement of riprap or brush-layered riprap, or fascine construction to stabilize stream banks.

Designs and measures will be based on available information and technical reports. 


\section{$\underline{\text { Recreation }}$}

Boulger Reservoir Dam - Reconstruct the dam to current State standards after determining that subsidence is complete. Dredge the reservoir to increase the life and enhance fishing quality. Water-right adjustment(s) associated with draining, filling, pool enlargement will be at the expense of the lessee/operator. Repair/replace the fish ladder structure, sidewalks, foot bridge, and vault toilet as needed to return them to serviceability.

Loss of Boulger Reservoir recreation use - Replacement/enhancement of recreational fishing opportunities. Measures considered could include the following, depending on available opportunities:

- Obtain lands or public easements (in the name of the United States) along existing reservoirs within the vicinity of the project area to provide continued flat water fishery opportunities to National Forest users.

- Purchasing water rights in adjacent reservoirs to establish a conservation pool to ensure that water is not drawn down beyond a threshold needed to ensure overwinter survival of trout.

Flat Canyon Campground - Improvement/enhancement of camping opportunities, measures considered could include:

- Improvement of dispersed recreation sites in Boulger and adjacent tributary canyons, including roads.

- Gravel parking pads and access roads.

- Purchase/placement of fire rings and tables.

- Post and pole fencing of closed dispersed recreation areas, as necessary.

- Purchase/placement of 3-4 vault toilets. 



\section{ATTACHMENT 3}

\section{EXPANDED AND CORRECTED TABLES 2.1 AND 2.2}

FROM FEIS, CHAPTER 2, SECTIONS 2.8 AND 2.9 

ATTACHMENT 3

Table 2.1, Comparison of Alternatives, Direct Physical Changes Due to Mining (Corrected/Expanded)

\begin{tabular}{|c|c|c|c|c|}
\hline \multirow{2}{*}{$\begin{array}{l}\text { PHYSICAL } \\
\text { CHANGE }\end{array}$} & \multicolumn{3}{|c|}{ ALTERNATIVES } & \multirow[b]{2}{*}{ Selected Alternative } \\
\hline & Alternative A & Alternatives B and B' & Alternative C & \\
\hline \multicolumn{5}{|c|}{\begin{tabular}{l|l} 
& Same as Altematives B and B', except no full-
\end{tabular}} \\
\hline General & $\begin{array}{l}\text { No mining of Federal or non- } \\
\text { Federal coal in project area. }\end{array}$ & $\begin{array}{l}\text { Two overlapping seams of full-extraction mining } \\
\text { (longwall and room-and-pillar) in majority of project } \\
\text { area. } \\
\text { One seam full-extraction mining in other areas } \\
\text { where both seams not mineable. } \\
\text { Full-support mining in peripheral areas of both } \\
\text { seams needed to access and develop full-extraction } \\
\text { areas. } \\
36 \text { million tons recoverable. } \\
\text { Extend mine life } 9 \text { to } 12 \text { years.. }\end{array}$ & $\begin{array}{l}\text { Same as Alternatives B and B', except no full- } \\
\text { extraction mining under perennial streams, } S R \text { - } \\
\text { 264, Flat Canyon Campground, and Boulger } \\
\text { Reservoir/Dam. } \\
\text { Only full-support room-and-pillar mining in } \\
\text { protected areas. } \\
\text { (no restriction under Cunningham Drainage) } \\
18 \text { to } 20 \text { million tons recoverable. } \\
\text { Extend mine life by } 5 \text { to } 7 \text { years. } \\
\text { The potential of receiving bids on the tract is } \\
\text { reduced. }\end{array}$ & $\begin{array}{l}\text { Same as Alternatives B and B', except only one } \\
\text { seam of full-extraction mining under perennial } \\
\text { streams, SR-264, Flat Canyon Campground, and } \\
\text { Boulger Reservoir/Dam. } \\
\text { Two overlapping seams of full-extraction mining } \\
\text { in remaining areas. } \\
\text { (no restriction under Cunningham Drainage) } \\
\text { Approximately } 28 \text { million tons recoverable. } \\
\text { Extend mine life up to } 7 \text { years. }\end{array}$ \\
\hline $\begin{array}{l}\text { Mine Discharge } \\
\text { Water }\end{array}$ & $\begin{array}{l}\text { No change. } \\
\text { Discharge recently increased } \\
\text { from less than } 1,000 \mathrm{gpm} \text { to } \\
15,000 \mathrm{gpm} \text {. }\end{array}$ & $\begin{array}{l}\text { Possibility of changing the mine water discharge } \\
\text { location from Eccles Creek to Electric Lake. } \\
\text { Discharge could increase an additional 7,000 gpm } \\
\text { over the } 15,000 \mathrm{gpm} \text { for Alternative A for a total of } \\
22,000 \mathrm{gpm} \text {. }\end{array}$ & $\begin{array}{l}\text { Same as Alternatives B and B' } \\
\text { Same as Alternatives B and B' }\end{array}$ & $\begin{array}{l}\text { Same as Alternatives B and B' } \\
\text { Same as Alternatives B and B' }\end{array}$ \\
\hline Vent Shafts & No effect & $\begin{array}{l}\text { Two air vent shafts with temporary access roads. } \\
\text { Temporary disturbance of } 2.9 \text { acres ( } 2.0 \text { acres for } \\
\text { pads and } 0.92 \text { acres for access roads). Possibility of } \\
\text { pumping mine water discharge from Swens Canyon } \\
\text { Shaft to Electric Lake requiring new buried pipeline } \\
\text { from shaft along Swens Canyon Road and SR-264. }\end{array}$ & Same as Alternative B and B' & Same as Alternative B and B' \\
\hline Exploration Holes & No effect & $\begin{array}{l}\text { About } 10 \text { additional boreholes with temporary } \\
\text { surface disturbance of } 9.2 \text { acres ( } 4.6 \text { acres for pads } \\
\text { and } 4.6 \text { acres for access roads) }\end{array}$ & Same as Alternatives $\mathrm{B}$ and $\mathrm{B}^{\prime}$ & Same as Alternatives B and B' \\
\hline
\end{tabular}

Attachment 3, Table 2.1

Page 1 
ATTACHMENT 3

Table 2.1, Comparison of Alternatives, Direct Physical Changes Due to Mining (Corrected/Expanded)

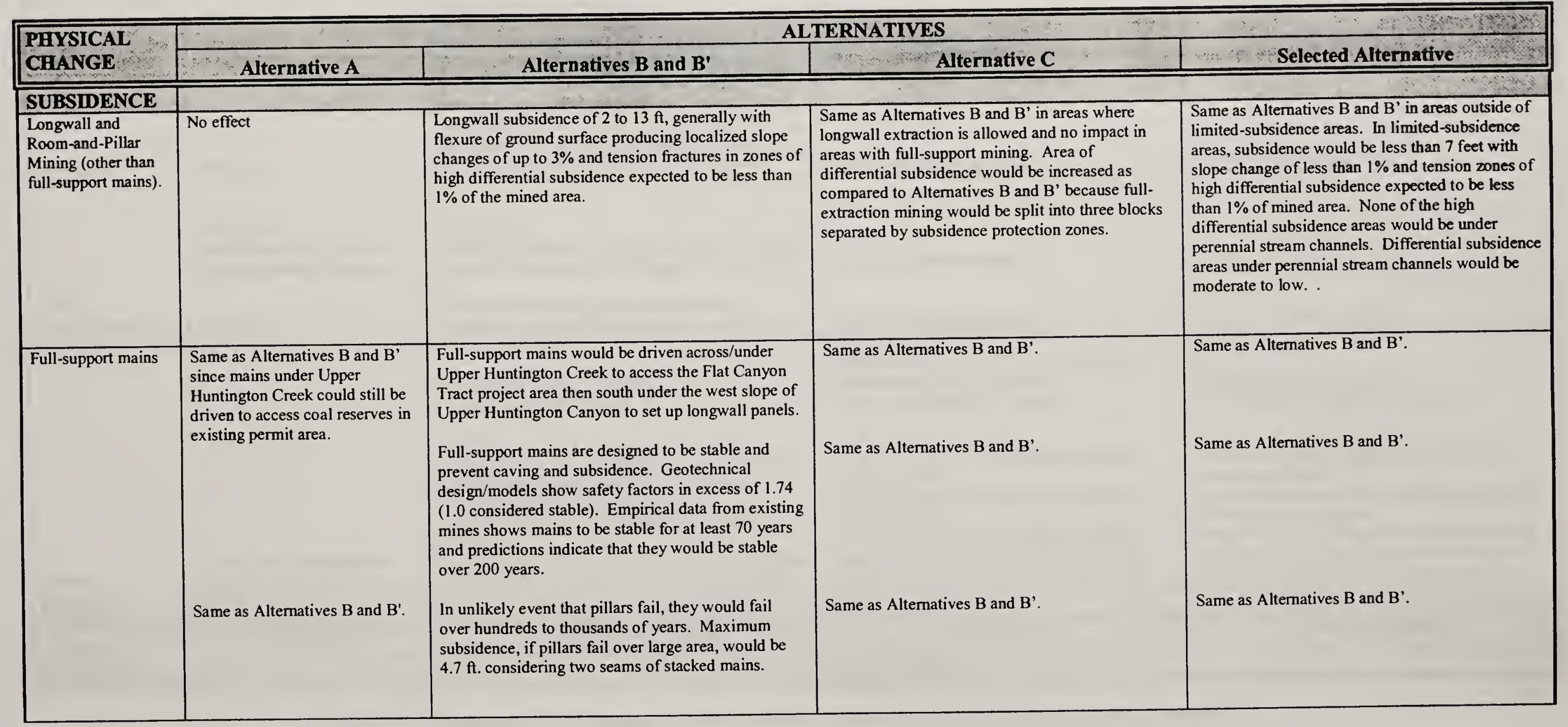

Attachment 3, Table 2.1

Page 2 
ATTACHMENT 3

Table 2.1, Comparison of Alternatives, Direct Physical Changes Due to Mining (Corrected/Expanded)

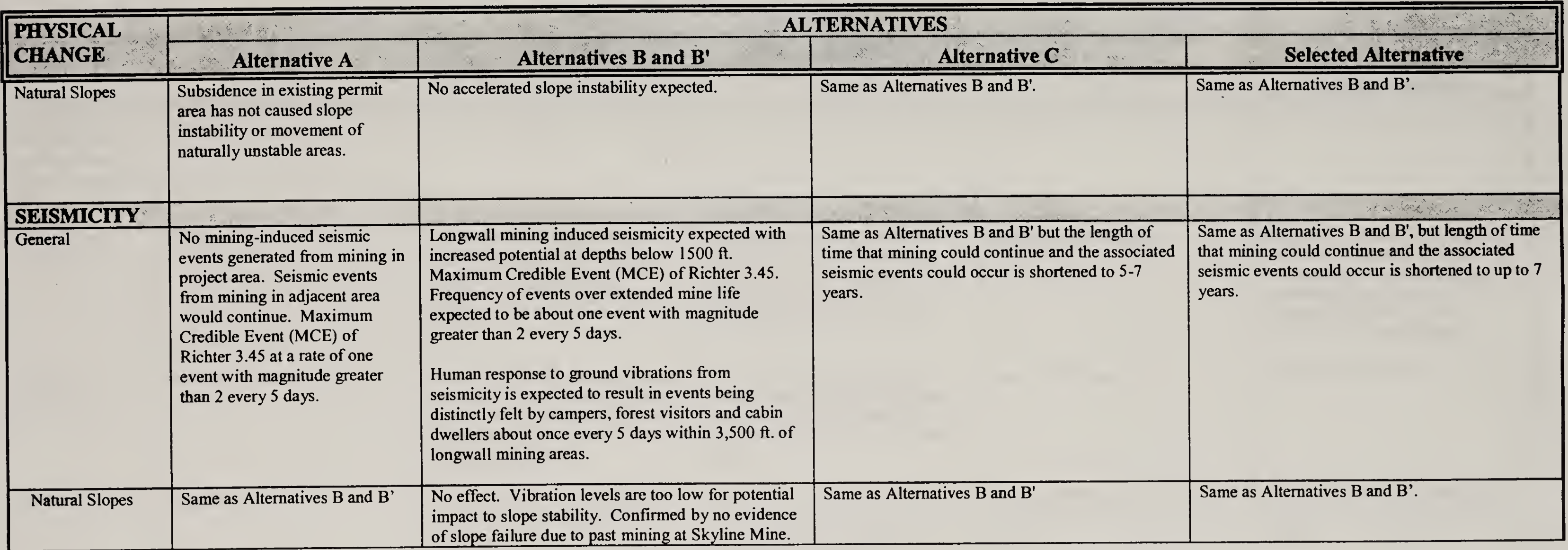

Attachment 3, Table 2.1

Page 3 

ATTACHMENT 3

Table 2.2, Comparison of Alternatives, Effects by Resource/Issue (Corrected/Expanded)

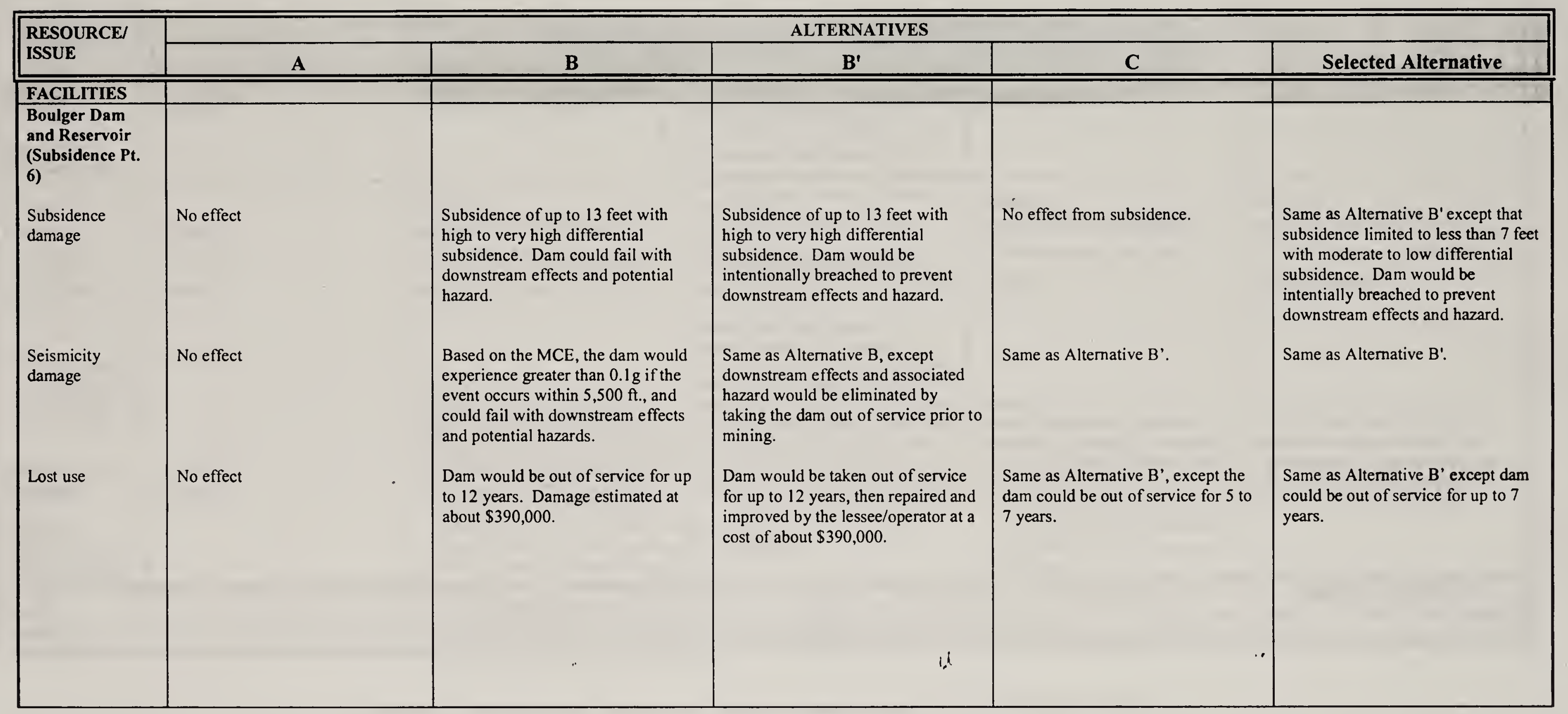

Attachment 3, Table 2.2

Page 1 
ATTACHMENT 3

Table 2.2, Comparison of Alternatives, Effects by Resource/Issue (Corrected/Expanded)

\begin{tabular}{|c|c|c|c|c|c|}
\hline \multirow{2}{*}{$\begin{array}{l}\text { RESOURCE/ } \\
\text { ISSUE }\end{array}$} & \multicolumn{5}{|c|}{ ALTERNATIVES } \\
\hline & $\mathbf{A}$ & B & $\mathbf{B}^{\prime}$ & $\mathrm{C}$ & Selected Alternative \\
\hline \multicolumn{6}{|c|}{$\begin{array}{l}\text { Highway SR } 264 \\
\text { (Subsidence Pts. } \\
5 \text { and 6) }\end{array}$} \\
\hline $\begin{array}{l}\text { Subsidence } \\
\text { damage }\end{array}$ & No effect & $\begin{array}{l}\text { Longwall mining subsidence of } 2 \text { to } \\
13 \mathrm{ft.} \text { with the possibility of minor } \\
\text { cracking of surface in some isolated } \\
\text { areas. Two major culverts could be } \\
\text { damaged. Damage estimated at } \\
\$ 52,000 \text {. }\end{array}$ & $\begin{array}{l}\text { Subsidence and damage to the road } \\
\text { are the same as Alternative B. SCLS } \\
\# 13 \text { would require monitoring and } \\
\text { repair by lessee/operator. Total cost } \\
\text { estimated at } \$ 52,000 \text {. Repairs could } \\
\text { include filling cracks and grading in } \\
\text { some areas with resurfacing of road } \\
\text { and replacement of culverts, but } \\
\text { without long-term effects. }\end{array}$ & $\begin{array}{l}\text { No effect. No longwall mining } \\
\text { within the subsidence angle-of-draw. } \\
\text { Projected full support pillars would } \\
\text { not cause subsidence. No cracks } \\
\text { expected. }\end{array}$ & $\begin{array}{l}\text { Same as Alternative B' except that } \\
\text { subsidence would be less than } 7 \text { feet } \\
\text { and the potential for cracks and } \\
\text { needed repairs would be reduced. }\end{array}$ \\
\hline Safety hazard & No effect & $\begin{array}{l}\text { Safety hazard exists without close } \\
\text { monitoring and immediate repairs. }\end{array}$ & $\begin{array}{l}\text { Safety hazard effectively avoided by } \\
\text { monitoring and immediate repairs. }\end{array}$ & No effect & Same as Alternative B'. \\
\hline $\begin{array}{l}\text { Seismicity } \\
\text { damage }\end{array}$ & No effect & $\begin{array}{l}\text { No effects from mining-induced } \\
\text { seismicity. }\end{array}$ & $\begin{array}{l}\text { No effects from mining-induced } \\
\text { seismicity. }\end{array}$ & $\begin{array}{l}\text { No effects from mining-induced } \\
\text { seismicity. }\end{array}$ & $\begin{array}{l}\text { No effects from mining-induced } \\
\text { seismicity. }\end{array}$ \\
\hline \multicolumn{6}{|c|}{$\begin{array}{l}\text { Unpaved Roads } \\
\text { (FS and pvt.) }\end{array}$} \\
\hline $\begin{array}{l}\text { Subsidence } \\
\text { damage }\end{array}$ & No effect & $\begin{array}{l}\text { Small cracks } 2 \text { inches or less } \\
\text { expected in tensile zones. Larger } \\
\text { cracks are possible but not likely. }\end{array}$ & $\begin{array}{l}\text { Subsidence and damage same as } \\
\text { Alternative B. }\end{array}$ & Same as Alternative B. & Same as Alternative B. \\
\hline
\end{tabular}

Attachment 3 , Table 2.2

Page 2 
ATTACHMENT 3

Table 2.2, Comparison of Alternatives, Effects by Resource/Issue (Corrected/Expanded)

\begin{tabular}{|c|c|c|c|c|c|}
\hline \multirow{2}{*}{$\begin{array}{l}\text { RESOURCE/ } \\
\text { ISSUE }\end{array}$} & \multicolumn{5}{|c|}{ ALTERNATIVES } \\
\hline & $\mathbf{A}$ & B & $\mathbf{B}^{\prime}$ & C & Selected Alternative \\
\hline Safety hazard & No effect & Minor safety risk to motorists. & $\begin{array}{l}\text { Monitoring required. Some repair } \\
\text { work required in tensile zones to fill } \\
\text { cracks and maintain slopes and } \\
\text { drainage with temporary safety } \\
\text { measures required. Cost of repair } \\
\text { estimated at less than } \$ 10,000 \text {. }\end{array}$ & Same as Alternative $\mathrm{B}^{\prime}$. & Same as Alternative B'. \\
\hline $\begin{array}{l}\text { Seismicity } \\
\text { damage }\end{array}$ & No effect & No effect from seismicity. & No effect from seismicity. & No effect from seismicity. & No effect from seismicity. \\
\hline $\begin{array}{l}\text { Flat Canyon } \\
\text { Campground } \\
\text { (Subsidence Pts } \\
5,6 \text {, and } 8 \text { ) }\end{array}$ & & & & & \\
\hline $\begin{array}{l}\text { Subsidence } \\
\text { damage }\end{array}$ & No effect & $\begin{array}{l}\text { Longwall mining subsidence of } 2 \text { to } \\
13 \mathrm{ft} \text {. with very low to moderate } \\
\text { differential subsidence. Minor } \\
\text { cracking of surface expected in some } \\
\text { areas. Water tank, water pipelines, } \\
\text { tables, toilets, septic tank/drain field, } \\
\text { spring collection system, and } \\
\text { retaining wall could be damaged. } \\
\text { Minor cracking of roads could occur. } \\
\text { Damage costs are estimated at } \\
\$ 150,000 \text { by the Forest Service. }\end{array}$ & $\begin{array}{l}\text { Same as Alternative B except that } \\
\text { SCLS \#13 would require monitoring } \\
\text { and repair by the lessee/operator. } \\
\text { Repair costs are estimated at } \\
\$ 150,000 \text {. }\end{array}$ & $\begin{array}{l}\text { No effect. Protected with no } \\
\text { subsidence of the structures allowed. } \\
\text { No possibility of cracks or } \\
\text { subsidence damage to facilities } \\
\text { provided pillar dimensions are } \\
\text { adequate. }\end{array}$ & $\begin{array}{l}\text { Same as Alternative B' except } \\
\text { subsidence would be less than } 7 \text { feet. } \\
\text { Potential damage reduced. }\end{array}$ \\
\hline
\end{tabular}

Attachment 3, Table 2.2

Page 3 
Table 2.2, Comparison of Alternatives, Effects by Resource/Issue (Corrected/Expanded)

\begin{tabular}{|c|c|c|c|c|c|}
\hline \multirow{2}{*}{$\begin{array}{l}\text { RESOURCE/ } \\
\text { ISSUE }\end{array}$} & \multicolumn{5}{|c|}{ ALTERNATIVES } \\
\hline & $\mathbf{A}$ & B & $\mathbf{B}^{\prime}$ & $\mathrm{C}$ & Selected Alternative \\
\hline $\begin{array}{l}\text { Seismicity } \\
\text { damage }\end{array}$ & No effect & $\begin{array}{l}\text { Longwall mining induced seismicity } \\
\text { has the potential to vibrate structures } \\
\text { once every } 5 \text { days at a Peak Particle } \\
\text { Velocity (PPV) of over } 1 \mathrm{in} / \mathrm{sec} \\
\text { within a range of } 3,500 \mathrm{ft} \text {. from } \\
\text { mining areas. Some minor cosmetic } \\
\text { damage may result with a very low } \\
\text { possibility of structural damage to } \\
\text { buildings for infrequent larger } \\
\text { events. No damage to the water } \\
\text { system is expected. } \\
\text { Some effects to recreation use at this } \\
\text { facility are expected. See } \\
\text { Recreation. }\end{array}$ & $\begin{array}{l}\text { Same as Alternative B, except that } \\
\text { lessee/operator would be required to } \\
\text { monitor and repair damage. } \\
\text { Some effects to recreation use at this } \\
\text { facility are expected. See } \\
\text { Recreation. }\end{array}$ & $\begin{array}{l}\text { Same as Alternative B'. } \\
\text { Some effects to recreation use at this } \\
\text { facility are expected. See } \\
\text { Recreation. }\end{array}$ & $\begin{array}{l}\text { Same as Alternative B'. } \\
\text { Some effects to recreation use at this } \\
\text { facility are expected. See } \\
\text { Recreation. }\end{array}$ \\
\hline $\begin{array}{l}\text { Flat Canyon } \\
\text { Cabins } \\
\text { (Subsidence Pt. } \\
\text { 5) } \\
\text { Subsidence } \\
\text { damage }\end{array}$ & No effect & $\begin{array}{l}\text { Longwall mining subsidence of } 2 \text { to } \\
4 \mathrm{ft} \text {., with very low to low } \\
\text { differential subsidence. Potential for } \\
\text { tensile strain and induced slope } \\
\text { changes with the possibility of } \\
\text { cracks. Lost use of facilities during } \\
\text { active subsidence. Cost of repairs } \\
\text { could reach } \$ 360,000 \text {. }\end{array}$ & $\begin{array}{l}\text { Same as Alternative B. Cabins, land } \\
\text { surface, and are in private } \\
\text { ownership. It is assumed that } \\
\text { monitoring and repairs would be } \\
\text { agreed upon by coal operator and } \\
\text { owners as required under state law. }\end{array}$ & $\begin{array}{l}\text { Most cabins protected due to no } \\
\text { longwall mining allowed for } \\
\text { protection of perennial drainage. } \\
\text { Two cabins north of canyon may be } \\
\text { subject to tensile strains at edge of } \\
\text { stacked pillars with some mitigation } \\
\text { required. Repair requirements are } \\
\text { same as Alternatives B'. }\end{array}$ & Same as Alternative B'. \\
\hline
\end{tabular}

Attachment 3, Table 2.2

Page 4 
ATTACHMENT 3

Table 2.2, Comparison of Alternatives, Effects by Resource/Issue (Corrected/Expanded)

\begin{tabular}{|c|c|c|c|c|c|}
\hline \multirow{2}{*}{$\begin{array}{l}\text { RESOURCE/ } \\
\text { ISSUE }\end{array}$} & \multicolumn{5}{|c|}{ ALTERNATIVES } \\
\hline & $\mathbf{A}$ & B & $\mathbf{B}^{\prime}$ & C & Selected Alternative \\
\hline $\begin{array}{l}\text { Seismicity } \\
\text { damage }\end{array}$ & No effect & $\begin{array}{l}\text { Longwall mining induced seismicity } \\
\text { has the potential to vibrate structures } \\
\text { once every } 5 \text { days. Some minor } \\
\text { cosmetic damage may result with a } \\
\text { very low possibility of structural } \\
\text { damage to buildings for infrequent } \\
\text { larger events. No damage to the } \\
\text { water systems is expected. }\end{array}$ & Same as Alternative B. & Same as Alternatives B and B'. & Same as Alternative $\mathbf{B}$ and $\mathbf{B}^{\prime}$. \\
\hline \multicolumn{6}{|c|}{$\begin{array}{l}\text { Swens Canyon } \\
\text { Cabins } \\
\text { (Subsidence Pt. } \\
\text { 3) }\end{array}$} \\
\hline $\begin{array}{l}\text { Subsidence } \\
\text { Damage }\end{array}$ & No effect & $\begin{array}{l}\text { Longwall mining subsidence of } 4 \text { to } \\
10 \mathrm{ft} \text {. with very low to high } \\
\text { differential'subsidence. Pillars at } \\
\text { edge of longwall area could result in } \\
\text { higher tensile strains with the } \\
\text { possibility of damage and lost use } \\
\text { during active subsidence. Estimated } \\
\text { repair cost included with Flat } \\
\text { Canyon cabins above. }\end{array}$ & $\begin{array}{l}\text { Same as Alternative B. Cabins, land } \\
\text { surface, and coal estates are in } \\
\text { private ownership. It is assumed that } \\
\text { monitoring and repairs would be } \\
\text { agreed upon by coal operator and } \\
\text { owners as required under state law. }\end{array}$ & $\begin{array}{l}\text { Similar to Alternative B, but could } \\
\text { be located above pillars giving rise } \\
\text { to greater tensile zone and greater } \\
\text { potential for damage. }\end{array}$ & $\begin{array}{l}\text { Similar to Alternative B', but } \\
\text { potential for damage reduced by } \\
\text { limiting subsidence to less than } 7 \\
\text { feet. }\end{array}$ \\
\hline $\begin{array}{l}\text { Seismicity } \\
\text { damage }\end{array}$ & No effect & $\begin{array}{l}\text { Same as discussion for Flat Canyon } \\
\text { cabins. }\end{array}$ & $\begin{array}{l}\text { Same as discussion for Flat Canyon } \\
\text { cabins. }\end{array}$ & Same as Alternatives B and B'. & Same as Alternatives B and B'. \\
\hline
\end{tabular}

Attachment 3, Table 2.2

Page 5 
ATTACHMENT 3

Table 2.2, Comparison of Alternatives, Effects by Resource/Issue (Corrected/Expanded)

\begin{tabular}{|c|c|c|c|c|c|}
\hline \multirow{2}{*}{$\begin{array}{l}\text { RESOURCE/ } \\
\text { ISSUE }\end{array}$} & \multicolumn{5}{|c|}{ ALTERNATIVES } \\
\hline & $\mathbf{A}$ & B & $\mathbf{B}^{\prime}$ & $\mathrm{C}$ & Selected Alternative \\
\hline \multicolumn{6}{|l|}{$\begin{array}{l}\text { Hunt Dam and } \\
\text { Reservoir }\end{array}$} \\
\hline $\begin{array}{l}\text { Subsidence } \\
\text { damage }\end{array}$ & No effect & $\begin{array}{l}\text { No effect from subsidence. Closest } \\
\text { mining and subsidence would be } \\
\text { over } 1,000 \mathrm{ft} \text {. distance. }\end{array}$ & Same as Alternative B. & Same as Alternatives B. & Same as Alternatives B. \\
\hline $\begin{array}{l}\text { Seismicity } \\
\text { damage }\end{array}$ & $\begin{array}{l}\text { No effect. Nearest mining is more } \\
\text { than } 5,500 \mathrm{ft} \text {. away. }\end{array}$ & $\begin{array}{l}\text { Mining-induced seismicity could } \\
\text { damage the dam. If the MCE of } \\
\text { magnitude } 3.45 \text { occurs within } 5,500 \\
\text { ft. the dam would experience greater } \\
\text { than } 0.1 \mathrm{~g} \text {. It could potentially be } \\
\text { taken out of service during active } \\
\text { mining within } 5,500 \mathrm{ft} \text {. resulting in a } \\
\text { loss of use. If damaged, repairs } \\
\text { would be required. Cost could reach } \\
\$ 390,000 \text {. It is assumed that an } \\
\text { agreement would be reached } \\
\text { between the lessee/operator and } \\
\text { private landowner to prevent } \\
\text { downstream effects and make } \\
\text { repairs. }\end{array}$ & Same as Alternative B. & Same as Alternatives B. & Same as Alternatives B. \\
\hline
\end{tabular}

Attachment 3, Table 2.2

Page 6 
ATTACHMENT 3

Table 2.2, Comparison of Alternatives, Effects by Resource/Issue (Corrected/Expanded)

\begin{tabular}{|c|c|c|c|c|c|}
\hline \multirow{2}{*}{$\begin{array}{l}\text { RESOURCE/ } \\
\text { ISSUE }\end{array}$} & \multicolumn{5}{|c|}{ ALTERNATIVES } \\
\hline & $\mathbf{A}$ & B & $\mathbf{B}^{\prime}$ & C & Selected Alternative \\
\hline \multicolumn{6}{|l|}{$\begin{array}{l}\text { SURFACE } \\
\text { WATER }\end{array}$} \\
\hline $\begin{array}{l}\text { Prolonged and } \\
\text { increased mine } \\
\text { water discharge } \\
\text { to Eccles Creek } \\
\text { and Scofield } \\
\text { Reservoir }\end{array}$ & $\begin{array}{l}\text { Discharge increased from less than } \\
1,000 \mathrm{gpm} \text { to } 10,000-15,000 \mathrm{gpm} \\
\text { after August } 2001 \text {. Could stop in } \\
2003 \text { if mine closes. } \\
\text { Chemical quality generally } \\
\text { consistent with beneficial use } \\
\text { standards, occasional exceedance } \\
\text { of phenol, total phosphorous, and } \\
\text { TDS. }\end{array}$ & $\begin{array}{l}\text { If Electric Lake UPDES Permit } \\
\text { obtained, discharge to Eccles Creek } \\
\text { would continue at approx. } 10,000 \\
\text { gpm. No change from Alternative } \\
\text { A, except discharge prolonged 9-12. } \\
\text { years. } \\
\text { If Electric Lake UPDES Permit } \\
\text { Denied, mine water discharge and } \\
\text { flow to Eccles Creek could increase } \\
\text { by } 7,000 \text { gpm to a maximum of } \\
22,000 \text { gpm and last an additional } 9 \text { - } \\
12 \text { years. } \\
\text { Chemical quality remain generally } \\
\text { the same and could improve. } \\
\text { Phosphorous loading to Scofield } \\
\text { Reservoir possible but not likely due } \\
\text { to recent decreased phosphorous } \\
\text { levels of discharge waters and } \\
\text { improved management. }\end{array}$ & $\begin{array}{l}\text { Same as Alternative B. } \\
\text { Same as Alternative B. }\end{array}$ & $\begin{array}{l}\text { Same as Alternatives B and B' } \\
\text { except that mine water discharge } \\
\text { could occur for a shorter time } \\
\text { (extended mine life of } 5 \text { to } 7 \text { years). } \\
\text { Same as Alternative B', but for a } \\
\text { shorter time (5-7 years). }\end{array}$ & $\begin{array}{l}\text { Same as Alternatives B and B' } \\
\text { except that mine water discharge } \\
\text { could occur for a shorter time } \\
\text { (extended mine life of up to } 7 \text { years) } \\
\text { Same as Alternative B', but for a } \\
\text { shorter time (up to } 7 \text { years). }\end{array}$ \\
\hline
\end{tabular}

Attachment 3, Table 2.2

Page 7 
ATTACHMENT 3

Table 2.2, Comparison of Alternatives, Effects by Resource/Issue (Corrected/Expanded)

\begin{tabular}{|c|c|c|c|c|c|}
\hline \multirow{2}{*}{$\begin{array}{l}\text { RESOURCE/ } \\
\text { ISSUE }\end{array}$} & \multicolumn{5}{|c|}{ ALTERNATIVES } \\
\hline & $\mathbf{A}$ & B & $\mathbf{B}^{\prime}$ & $\mathrm{C}$ & Selected Alternative \\
\hline & $\begin{array}{l}\text { Significant erosion of Mud Creek } \\
\text { channel and resulting sediment } \\
\text { increases to Scofield Reservoir. } \\
\text { Piping of some discharge directly } \\
\text { to Scofield Reservoir could reduce } \\
\text { effects. }\end{array}$ & $\begin{array}{l}\text { if Electric Lake UPDES Permit } \\
\text { obtained, stream morphology effects } \\
\text { to Eccles and Mud Creeks same as } \\
\text { Alternative A. } \\
\text { If Electric Lake UPDES Permit } \\
\text { Denied, erosion of Mud Creek and } \\
\text { sediment transport to Scofield } \\
\text { Reservoir would increase relative to } \\
\text { Alternative A. Piping of some } \\
\text { discharge directly to Scofield } \\
\text { Reservoir could reduce effects. }\end{array}$ & $\begin{array}{l}\text { Same as Alternative B. } \\
\text { Same as Alternative B. }\end{array}$ & $\begin{array}{l}\text { Same as Alternative B', but for a } \\
\text { shorter time (5-7 years). } \\
\text { Same as Alternative B', but for a } \\
\text { shorter time (5-7 years). }\end{array}$ & $\begin{array}{l}\text { Same as Alternative B', but for a } \\
\text { shorter time (up to } 7 \text { years). } \\
\text { Same as Alternative B', but for a } \\
\text { shorter time (up to } 7 \text { years). }\end{array}$ \\
\hline $\begin{array}{l}\text { A new mine } \\
\text { water discharge } \\
\text { point in Electric } \\
\text { Lake, Changing } \\
\text { some or all of the } \\
\text { mine water } \\
\text { discharge from } \\
\text { Eccles Creek to } \\
\text { Electric Lake. } \\
\text { Decrease now in } \\
\text { Price River } \\
\text { Watershed and } \\
\text { increase flow in } \\
\text { Huntington } \\
\text { Canyon } \\
\text { Watershed. }\end{array}$ & $\begin{array}{l}\text { Flow } \\
\text { Current discharge to Eccles Creek } \\
\text { is } 10,000 \text { to } 15,000 \mathrm{gpm} \text {. } \\
\text { Current ground water discharge } \\
\text { from James Canyon wells to } \\
\text { Electric Lake is } 2,000-4,000 \mathrm{gpm} \text {. } \\
\text { Expected to stabilize at } 5,000 \\
\text { gpm. Expected to continue to } \\
2003 \text {. }\end{array}$ & $\begin{array}{l}\text { Fiow } \\
\text { if Eiectric Lake UPDES Permit } \\
\text { issued, } 12,000 \text { mine water } \\
\text { discharged to Electric Lake for } 9-12 \\
\text { years. Increase of } 19,350 \text { ac-ft } \\
\text { annual increase representing } 33 \% \text { of } \\
\text { Electric Lake capacity. } \\
\text { if Electric Lake UPDES denied, no } \\
\text { change to Electric Lake but flow to } \\
\text { Eccles Creek increased by } 7,000 \text { - } \\
\text { i } 2,000 \text { gpm for } 9-12 \text { years for a total } \\
\text { of } 22,000 \text { gpm. Increase of } 12,000 \\
\text { gpm is i } 9,350 \text { ac-ft annually, } \\
\text { representing } 26 \% \text { of Scofield } \\
\text { Reservoir capacity. } \\
\text { Under either scenario, discharge to } \\
\text { Eccles Creek would remain above } \\
\text { pre-August } 2001 \text { flows. }\end{array}$ & $\begin{array}{l}\underline{\text { Flow }} \\
\text { Same as Alternative B. }\end{array}$ & $\begin{array}{l}\text { Flow } \\
\text { Same as Alternative B', except that } \\
\text { discharge would occur for a shorter } \\
\text { time (5-7 years).. }\end{array}$ & $\begin{array}{l}\text { Flow } \\
\text { Same as Alternative B', except that } \\
\text { discharge would occur for a shorter } \\
\text { time (up to } 7 \text { years).. }\end{array}$ \\
\hline
\end{tabular}

\section{Attachment 3, Table 2.2}

Page 8 
ATTACHMENT 3

Table 2.2, Comparison of Alternatives, Effects by Resource/Issue (Corrected/Expanded)

\begin{tabular}{|c|c|c|c|c|c|}
\hline \multirow{2}{*}{$\begin{array}{l}\text { RESOURCE/ } \\
\text { ISSUE }\end{array}$} & \multicolumn{5}{|c|}{ ALTERNATIVES } \\
\hline & 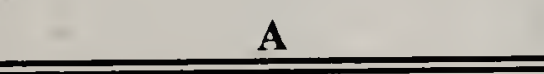 & $\mathbf{B}$ & $\mathbf{B}^{\prime}$ & $\mathrm{C}$ & Selected Alternative \\
\hline $\begin{array}{l}\text { Change water } \\
\text { quality in } \\
\text { receiving } \\
\text { streams. }\end{array}$ & $\begin{array}{l}\text { Quality } \\
\text { Negligible change to Electric Lake } \\
\text { since ground water discharged is } \\
\text { very good quality. }\end{array}$ & $\begin{array}{l}\text { Quality } \\
\text { Possible, but unlikely, increase in } \\
\text { phosphorous in Electric Lake. } \\
\text { Possible, but unlikely, accelerated } \\
\text { eutrophication. Water temperature } \\
\text { increase at discharge outlet. }\end{array}$ & $\begin{array}{l}\text { Quality } \\
\text { Same as Alternative B, but some } \\
\text { mitigations potentially required if } \\
\text { eutrophication occurs. }\end{array}$ & $\begin{array}{l}\text { Quality } \\
\text { Same as Alternative B', but for a } \\
\text { shorter time ( } 5-7 \text { years). }\end{array}$ & $\begin{array}{l}\text { Quality } \\
\text { Same as Alternative B', but for a } \\
\text { shorter time (up to } 7 \text { years). }\end{array}$ \\
\hline $\begin{array}{l}\text { Subsidence of } \\
\text { perennial } \\
\text { streams and } \\
\text { Boulger Res. } \\
\text { could intercept } \\
\text { water and divert } \\
\text { it underground. }\end{array}$ & No effect & $\begin{array}{l}\text { No loss of water expected due to } \\
\text { deep overburden and sealing } \\
\text { characteristics of clay in shales. If it } \\
\text { should occur, state appropriated } \\
\text { waters would be replaced by the } \\
\text { lessee/operator's expense. }\end{array}$ & $\begin{array}{l}\text { Same as Alternative B, except that } \\
\text { SCLS \#17 would require } \\
\text { replacement of all waters identified } \\
\text { for protection including } \\
\text { unappropriated water needed for } \\
\text { ecosystems. }\end{array}$ & $\begin{array}{l}\text { No effect because subsidence would } \\
\text { be prevented except for the } \\
\text { Cunningham Drainage. No loss of } \\
\text { water expected due to deep } \\
\text { overburden and sealing } \\
\text { characteristics of clay in shales. In } \\
\text { the event that loss occurs due to } \\
\text { mining, SCLS \#17 would require } \\
\text { replacement of all waters identified } \\
\text { for protection including } \\
\text { unappropriated water needed for } \\
\text { ecosystems. }\end{array}$ & Same as Alternative B'. \\
\hline
\end{tabular}

Attachment 3, Table 2.2

Page 9 
ATTACHMENT 3

Table 2.2, Comparison of Alternatives, Effects by Resource/Issue (Corrected/Expanded)

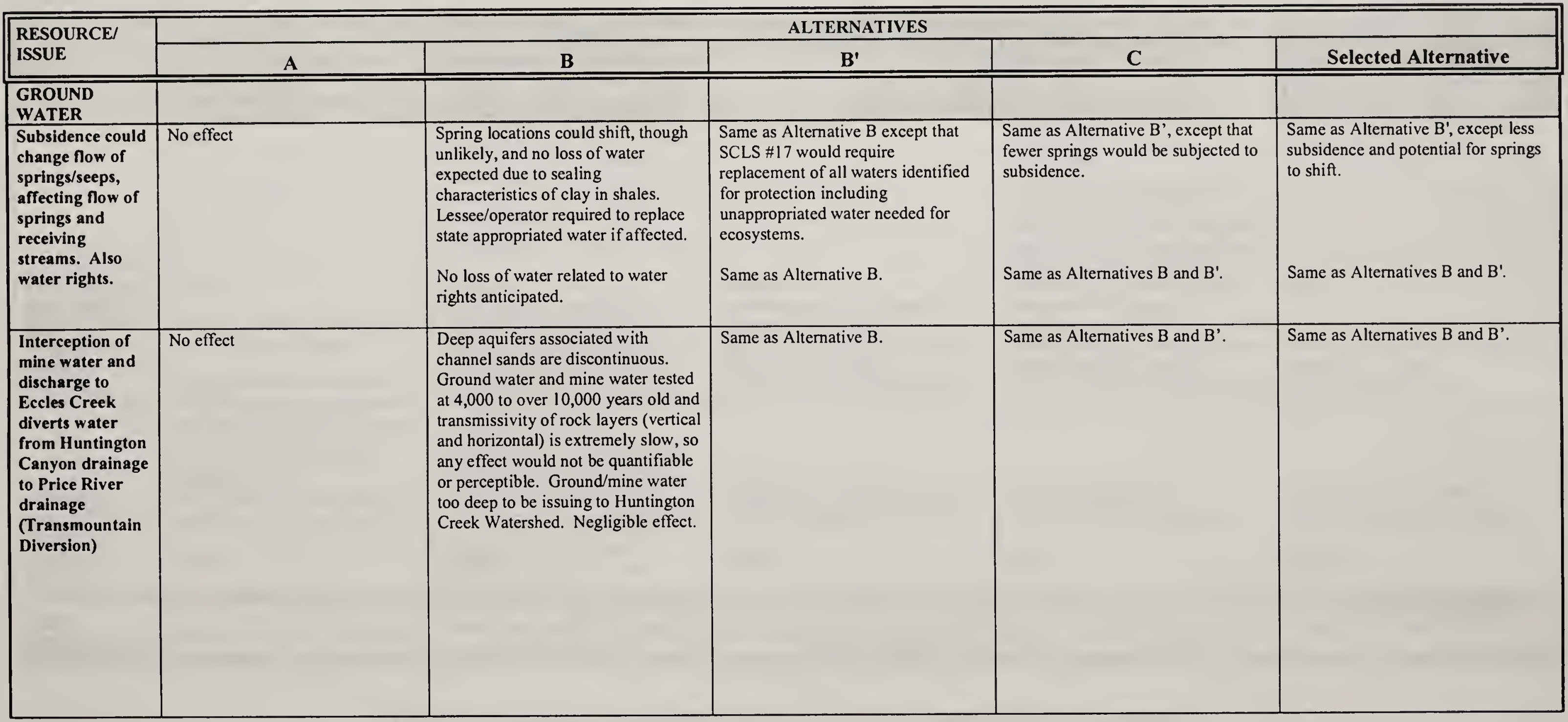

Attachment 3, Table 2.2

Page 10 
ATTACHMENT 3

Table 2.2, Comparison of Alternatives, Effects by Resource/Issue (Corrected/Expanded)

\begin{tabular}{|c|c|c|c|c|c|}
\hline \multirow{2}{*}{$\begin{array}{l}\text { RESOURCE/ } \\
\text { ISSUE }\end{array}$} & \multicolumn{5}{|c|}{ ALTERNATIVES } \\
\hline & $\mathbf{A}$ & B & $\mathbf{B}^{\prime}$ & C & Selected Alternative \\
\hline $\begin{array}{l}\text { Water Quality } \\
\text { Effects from } \\
\text { Equipment Left } \\
\text { Underground }\end{array}$ & No effect & $\begin{array}{l}\text { Local ground water quality could be } \\
\text { degraded by oils and other fluids } \\
\text { (battery acid, transmission oil, diesel } \\
\text { fuel, lubricants, etc.) if leaked } \\
\text { underground and slow } \\
\text { corrosion/oxidation of metals left } \\
\text { underground. See mine water } \\
\text { discharge in Surface Water Section. } \\
\text { Connection with surface waters is } \\
\text { very slow and unlikely, therefore } \\
\text { effects are expected to be negligible. }\end{array}$ & $\begin{array}{l}\text { Same as Alternative B, but SCLS } \\
\# 19 \text { would require removal of } \\
\text { equipment unless specifically } \\
\text { approved. } \\
\text { Less potential for contamination } \\
\text { because equipment and materials left } \\
\text { underground would be limited to } \\
\text { inert materials, corrosion/oxidation } \\
\text { resistant metals, and non-polluting } \\
\text { fluids. }\end{array}$ & Same as Alternative B'. & Same as Alternative B'. \\
\hline \multicolumn{6}{|l|}{ VEGETATION } \\
\hline $\begin{array}{l}\text { Disturbance } \\
\text { from Surface } \\
\text { Facilities }\end{array}$ & No effect & $\begin{array}{l}\text { Temporary ( } 3-5 \text { yrs.) removal of } 2.9 \\
\text { acres of vegetation for vent shafts } \\
\text { and } 9.2 \text { acres for exploration drill } \\
\text { holes. Long-term ( } 12-15 \text { years) loss } \\
\text { of vegetation affected for vent shafts } \\
\text { of less than } 1 \text { acre. }\end{array}$ & Same as Alternative B. & $\begin{array}{l}\text { Same as Alternatives B and } \mathrm{B}^{\prime} \text {, } \\
\text { except long-term loss of vegetation } \\
\text { at vent shafts reduced to } 5-7 \text { years. }\end{array}$ & $\begin{array}{l}\text { Same as Alternatives B and B', } \\
\text { except long-term loss of vegetation } \\
\text { at vent shafts reduced to up to } 7 \\
\text { years. }\end{array}$ \\
\hline $\begin{array}{l}\text { Subsidence } \\
\text { disturbance. }\end{array}$ & No effect & $\begin{array}{l}\text { Changes in stream morphology in } \\
\text { Swens Canyon, Little Swens } \\
\text { Canyon, Boulger Canyon, and Flat } \\
\text { Canyon could result in loss of } \\
\text { streambank riparian vegetation from } \\
\text { scouring. Increase in pond areas } \\
\text { could increase riparian over the } \\
\text { long-term after all subsidence is } \\
\text { complete (increased land/water } \\
\text { contact area). }\end{array}$ & $\begin{array}{l}\text { Same effects as Alternative B but } \\
\text { SCLS } \# 3 \text { and } \# 7 \text { require vegetation } \\
\text { baseline information and monitoring } \\
\text { necessary to quantify changes. }\end{array}$ & No effect & $\begin{array}{l}\text { Similar to B' except that the potential } \\
\text { for vegetation loss is reduced by } \\
\text { limiting subsidence to less than } 7 \\
\text { feet. Intensive monitoring would } \\
\text { occur and lessee/operator required to } \\
\text { mitigate effects by completing } \\
\text { stream channel rehabilitation and } \\
\text { stabilization measures and planting } \\
\text { riparian vegetation. }\end{array}$ \\
\hline
\end{tabular}

Attachment 3, Table 2.2

Page 11 
ATTACHMENT 3

Table 2.2, Comparison of Alternatives, Effects by Resource/Issue (Corrected/Expanded)

\begin{tabular}{|c|c|c|c|c|c|}
\hline \multirow{2}{*}{$\begin{array}{l}\text { RESOURCE/ } \\
\text { ISSUE }\end{array}$} & \multicolumn{5}{|c|}{ ALTERNATIVES } \\
\hline & $\mathbf{A}$ & B & $\mathbf{B}^{\prime}$ & C & Selected Alternative \\
\hline & No effect & $\begin{array}{l}\text { Spring locations could shift causing } \\
\text { associated localized riparian } \\
\text { vegetation to shift. Temporary loss } \\
\text { during adjustment. }\end{array}$ & $\begin{array}{l}\text { Same as Alternative } B, \text { except SCLS } \\
\# 3 \text { and } \# 7 \text { would require vegetation } \\
\text { baseline information and monitoring } \\
\text { necessary to quantify changes. }\end{array}$ & $\begin{array}{l}\text { Same as Alternative B', but fewer } \\
\text { springs subjected to subsidence. }\end{array}$ & $\begin{array}{l}\text { Same as Alternative B' but potential } \\
\text { for effects reduced by limiting } \\
\text { subsidence to less than } 7 \text { feet. }\end{array}$ \\
\hline $\begin{array}{l}\text { Increased } \\
\text { discharge to } \\
\text { Eccles Creek if } \\
\text { Electric Lake } \\
\text { UPDES Permit } \\
\text { not issued. }\end{array}$ & No Effect & $\begin{array}{l}\text { Increase of discharge to Eccles } \\
\text { Creek from } 10,000-15,000 \mathrm{gpm} \text { to } \\
22,000 \mathrm{gpm} \text {. Could increase } \\
\text { headcutting in Eccles and Mud } \\
\text { Creeks. This could cause loss of } \\
\text { riparian vegetation for many years, } \\
\text { until channels stabilize and } \\
\text { vegetation recovers. Could be } \\
\text { reduced by piping some discharge } \\
\text { directly to Scofield Reservoir. }\end{array}$ & Same as Alternative B. & $\begin{array}{l}\text { Same as Alternatives B and B', but } \\
\text { for less time ( } 5-7 \text { years). }\end{array}$ & $\begin{array}{l}\text { Same as Alternatives B and B', but } \\
\text { for less time (up to } 7 \text { years). }\end{array}$ \\
\hline $\begin{array}{l}\text { Threatened, } \\
\text { Endangered, and } \\
\text { Sensitive Species }\end{array}$ & No effect & No effect & $\begin{array}{c}\text { No effect } \\
\text {, , . }\end{array}$ & No effect & No effect \\
\hline \multicolumn{6}{|l|}{ WILDLIFE } \\
\hline \multicolumn{6}{|c|}{ 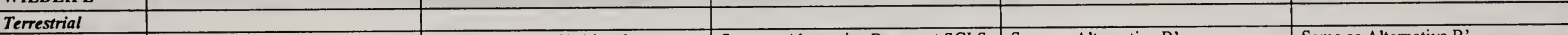 } \\
\hline $\begin{array}{l}\text { Disturbance } \\
\text { from Surface } \\
\text { Facilities }\end{array}$ & No effect & $\begin{array}{l}\text { Short-term loss of habitat for } \\
\text { exploratory drilling and } \\
\text { construction/drilling of vent shafts } \\
\text { due to avoidance. Sensitive bird } \\
\text { species (individuals) could be } \\
\text { affected during nesting season, } \\
\text { causing abandonment. }\end{array}$ & $\begin{array}{l}\text { Same as Alternative B, except SCLS } \\
\# 14 \text { reduces effects to sensitive } \\
\text { species and species of high interest } \\
\text { by imposing appropriate timing } \\
\text { restrictions on construction and } \\
\text { drilling operations. Does not affect } \\
\text { operation of vent holes, once } \\
\text { constructed. }\end{array}$ & Same as Alternative B'. & Same as Alternative B'. \\
\hline
\end{tabular}

Attachment 3, Table 2.2

Page 12 
ATTACHMENT 3

Table 2.2, Comparison of Alternatives, Effects by Resource/Issue (Corrected/Expanded)

\begin{tabular}{|c|c|c|c|c|c|}
\hline \multirow{2}{*}{$\begin{array}{l}\text { RESOURCE/ } \\
\text { ISSUE }\end{array}$} & \multicolumn{5}{|c|}{ ALTERNATIVES } \\
\hline & $\mathbf{A}$ & B & $\mathbf{B}^{\prime}$ & $\mathrm{C}$ & Selected Alternative \\
\hline $\begin{array}{l}\text { Subsiden ce/Seis } \\
\text { micity }\end{array}$ & No effect & 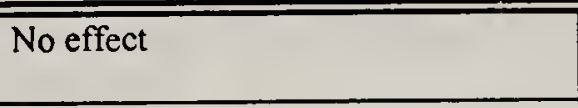 & $\overline{\text { No effect }}$ & No effect & No effect \\
\hline Aquatic & & & & & \\
\hline $\begin{array}{l}\text { Disturbance } \\
\text { from Surface } \\
\text { Facilities }\end{array}$ & No effect & $\begin{array}{l}\text { Crossing Boulger Canyon and } \\
\text { Swens Can yon could add minor } \\
\text { amounts of sediment to creeks. Use } \\
\text { of bridges or bottomless arches } \\
\text { would reduce streambed disturbance, } \\
\text { therefore negligible effect to habitat. }\end{array}$ & Same as Alternative B. & Same as Alternatives B and B'. & Same as Alternatives B and B'. \\
\hline
\end{tabular}


ATTACHMENT 3

Table 2.2, Comparison of Alternatives, Effects by Resource/Issue (Corrected/Expanded)

\begin{tabular}{|c|c|c|c|c|c|}
\hline \multirow{2}{*}{$\begin{array}{l}\text { RESOURCE/ } \\
\text { ISSUE }\end{array}$} & \multicolumn{5}{|c|}{ * $\cdot$, ALTERNATIVES } \\
\hline & $\mathbf{A}$ & B & $\mathbf{B}^{\prime}$ & $\mathrm{C}$ & Selected Alternative \\
\hline $\begin{array}{l}\text { Subsidence } \\
\text { caused changes } \\
\text { in stream } \\
\text { gradient/morpho } \\
\text { logy/flow/quality } \\
\text { could affect } \\
\text { habitat. }\end{array}$ & No effect & $\begin{array}{l}\text { Stream morphology changes and } \\
\text { sediment additions in streams could } \\
\text { decrease habitat quality and } \\
\text { productivity for aquatic species in } \\
\text { perennial drainages with gradients of } \\
5 \% \text { or less including the majority of } \\
\text { Boulger Creek, ( } 4.0 \text { miles), lower } \\
\text { portions of Swens }(0.5 \text { mile) and } \\
\text { Little Swens ( } 0.5 \text { mile) Canyons, and } \\
\text { in Flat Canyon ( } 1.5 \text { miles). } \\
\text { Individuals affected but population } \\
\text { viability not lost. Recovery could } \\
\text { take } 10-30 \text { years after subsidence. } \\
\text { No flow changes expected (see } \\
\text { Surface and Ground Water). } \\
\text { Macroinvertebrate indices could fall } \\
\text { below Forest Plan Standards for } 10- \\
30 \text { years. }\end{array}$ & $\begin{array}{l}\text { Same effects as Alternative B, but } \\
\text { SCLS } \# 3 \text { and } \# 7 \text { would require } \\
\text { monitoring to quantify effects to } \\
\text { habitat and aquatic species and } \\
\text { potentially require measures to } \\
\text { mitigate effects. Measures would } \\
\text { only partially decrease effects. } \\
\text { Macroinvertebrate indices could fall } \\
\text { below Forest Plan Standards but } \\
\text { probably for less time than } \\
\text { Alternative B due to mitigation } \\
\text { measures. }\end{array}$ & $\begin{array}{l}\text { No effect except for Cunningham } \\
\text { Drainage. Negligible effects } \\
\text { because stream gradient is steeper } \\
\text { than } 5 \% \text { (similar to Bumout } \\
\text { Canyon). } \\
\text { No effect }\end{array}$ & $\begin{array}{l}\text { Same as B' except that the } \\
\text { magnitude of effects reduced by } \\
\text { limiting subsidence to less than } 7 \\
\text { feet and slope change to less than } \\
1 \% \text {. } \\
\text { Macroinvertebrate indices could } \\
\text { decrease but Forest Plan Standards } \\
\text { likely maintained through intensive } \\
\text { monitoring and stream rehabilitation } \\
\text { measures }\end{array}$ \\
\hline Seismicity & No effect & No effect & No effect & No effect & No effect \\
\hline
\end{tabular}

Attachment 3, Table 2.2

Page 14 
ATTACHMENT 3

Table 2.2, Comparison of Alternatives, Effects by Resource/Issue (Corrected/Expanded)

\begin{tabular}{|c|c|c|c|c|c|}
\hline \multirow{2}{*}{$\begin{array}{l}\text { RESOURCE/ } \\
\text { ISSUE }\end{array}$} & \multicolumn{5}{|c|}{ ALTERNATIVES } \\
\hline & $\mathbf{A}$ & B & $\mathbf{B}^{\prime}$ & C & Selected Alternative \\
\hline $\begin{array}{l}\text { Mine Water } \\
\text { Discharge }\end{array}$ & $\begin{array}{l}\text { Increased discharge to Eccles } \\
\text { Creek and Scofield Reservoir from } \\
\text { less than 1,000 gpm to } 10,000 \text { to } \\
15,000 \mathrm{gpm} \text { could cause decrease } \\
\text { in aquatic habitat anticipated. } \\
\text { Piping of some discharge directly } \\
\text { to Scofield Reservoir could reduce } \\
\text { effects. }\end{array}$ & $\begin{array}{l}\text { Mine water discharge increased by } \\
9 \text {-12 years. } \\
\text { Discharge to Eccles Creek could } \\
\text { increase to } 22,000 \text { gpm if Electric } \\
\text { Lake UPDES Permit not approved. } \\
\text { Changes to stream morphology and } \\
\text { riparian vegetation in Eccles and } \\
\text { Mud Creeks could cause habitat } \\
\text { degradation for many years. Quality } \\
\text { changes expected to be negligible. } \\
\text { Effects could be reduced by piping } \\
\text { some discharge directly to Scofield } \\
\text { Reservoir. } \\
\text { If discharge to Electric Lake } \\
\text { approved, effects to Eccles Creek } \\
\text { and Scofield Reservoir same as } \\
\text { Alternative A. } \\
\text { If discharge to Electric Lake is } \\
\text { approved, degradation of water } \\
\text { quality from mine water discharge } \\
\text { could occur due to phosphorous and } \\
\text { associated eutrophication, but not } \\
\text { likely due to recent improved quality } \\
\text { of discharge water and improved } \\
\text { management. }\end{array}$ & $\begin{array}{l}\text { Same as Alternative B. } \\
\text { Same as Alternative B. } \\
\text { Same as Alternative B. } \\
\text { Same as Alternative B, except that } \\
\text { monitoring and mitigations could } \\
\text { reduce effects.. }\end{array}$ & $\begin{array}{l}\text { Same as Alternatives B, but mine } \\
\text { water discharge would occur for a } \\
\text { shorter time (5-7 years). } \\
\text { Same as Alternative B, but for } \\
\text { shorter time. } \\
\text { Same as Alternative B, but for } \\
\text { shorter time. } \\
\text { Same as Alternative B', except that } \\
\text { discharge would occur for shorter } \\
\text { time (5-7 years). }\end{array}$ & $\begin{array}{l}\text { Same as Alternative B, but for } \\
\text { shorter time. } \\
\text { Same as Alternative B', except that } \\
\text { discharge would occur for shorter } \\
\text { time (up to } 7 \text { years). }\end{array}$ \\
\hline
\end{tabular}




\section{ATTACHMENT 3}

Table 2.2, Comparison of Alternatives, Effects by Resource/Issue (Corrected/Expanded)

\begin{tabular}{|l|l|l|l|l|l|}
\hline $\begin{array}{l}\text { RESOURCE/ } \\
\text { ISSUE }\end{array}$ & \multicolumn{1}{|c|}{ A } & \multicolumn{1}{|c|}{ B } & \multicolumn{1}{c|}{ B' $^{\prime}$} & \multicolumn{1}{c|}{ Celected Alternative } \\
\cline { 2 - 6 } & & Negligible effects & Negligible effects & Negligible effects \\
\hline $\begin{array}{l}\text { Threatened, } \\
\text { Endangered, and }\end{array}$ & No effect & & & Negligible effects \\
\hline RECREATION & & $\begin{array}{l}\text { Single-season degradation of } \\
\text { recreation experience in Boulger } \\
\text { Canyon and Swens Canyons during } \\
\text { construction of vent shafts. } \\
\text { One to two season degradation of } \\
\text { recreation experience for coal } \\
\text { drilling in any specific area. }\end{array}$ & Same as Alternative B. & Same as Alternative B. \\
$\begin{array}{l}\text { Disturbance } \\
\text { from Surface } \\
\text { Facilities }\end{array}$ & No effect & Same as Alternatives B and B'. & Same as Alternatives B and B'. \\
\hline
\end{tabular}


ATTACHMENT 3

Table 2.2, Comparison of Alternatives, Effects by Resource/Issue (Corrected/Expanded)

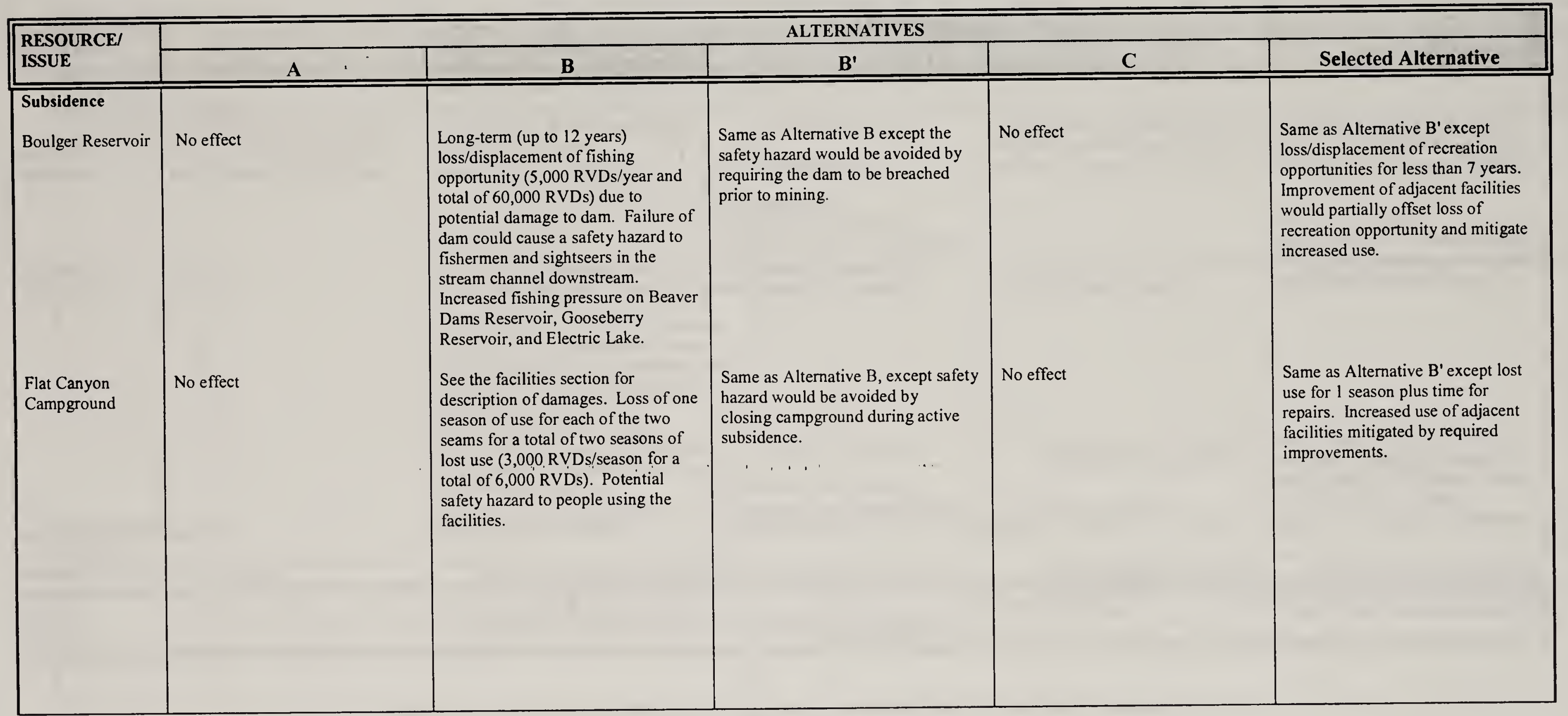

Attachment 3, Table 2.2

Page 17 


\section{ATTACHMENT 3}

Table 2.2, Comparison of Alternatives, Effects by Resource/Issue (Corrected/Expanded)

\begin{tabular}{|c|c|c|c|c|c|}
\hline \multirow{2}{*}{$\begin{array}{l}\text { RESOURCE/ } \\
\text { ISSUE }\end{array}$} & \multicolumn{5}{|c|}{ ALTERNATIVES } \\
\hline & $\mathbf{A}$ & B & $\mathbf{B}^{\prime}$ & $\mathrm{C}$ & Selected Alternative \\
\hline \multicolumn{6}{|l|}{ Seismicity } \\
\hline Boulger Reservoir & No effect & $\begin{array}{l}\text { Dam could be damaged by } \\
\text { seismicity (see Facilities). Long- } \\
\text { term (up to } 12 \text { years) } \\
\text { loss/displacement of fishing } \\
\text { opportunity ( } 5,000 \text { RVDs/year and } \\
\text { total of } 60,000 \text { RVDs). Potential } \\
\text { safety hazard to fishermen and } \\
\text { sightseers in channel downstream. } \\
\text { Increased fishing pressure on Beaver } \\
\text { Dams Reservoir, Gooseberry } \\
\text { Reservoir, and Electric Lake. }\end{array}$ & $\begin{array}{l}\text { Same as Alternative B, except safety } \\
\text { hazard avoided by requiring dam to } \\
\text { be breached prior to mining. }\end{array}$ & $\begin{array}{l}\text { Same as Alternative B', except lost } \\
\text { use reduced to 5-7 years.. }\end{array}$ & $\begin{array}{l}\text { Same as Alternative B', except lost } \\
\text { use up to } 7 \text { years. Required } \\
\text { mitigations would offset lost use and } \\
\text { mitigate increased use of other } \\
\text { adjacent facilities. }\end{array}$ \\
\hline $\begin{array}{l}\text { Flat Canyon } \\
\text { Campground }\end{array}$ & No effect & $\begin{array}{l}\text { Some minor potential for damage } \\
\text { (see Facilities) that could cause a } \\
\text { low safety hazard. }\end{array}$ & $\begin{array}{l}\text { Safety hazard avoided because } \\
\text { campground closed due to } \\
\text { subsidence concerns. Campground } \\
\text { closed for two seasons (see } \\
\text { subsidence above). }\end{array}$ & No effect. & $\begin{array}{l}\text { Same as Alternative } B^{\prime} \text {, but } \\
\text { campground closed for } 1 \text { season and } \\
\text { time for repairs. Lost use mitigated } \\
\text { by required measures. }\end{array}$ \\
\hline $\begin{array}{l}\text { Dispersed } \\
\text { recreation }\end{array}$ & $\begin{array}{l}\text { Events greater than magnitude } 2 \\
\text { could be perceived once every } 5 \\
\text { days within } 3,500 \mathrm{ft} \text {. of existing } \\
\text { permit area. }\end{array}$ & $\begin{array}{l}\text { Human response to ground } \\
\text { vibrations from seismicity is } \\
\text { expected to result in events being } \\
\text { distinctly felt by campers, forest } \\
\text { visitors and cabin dwellers about } \\
\text { once every } 5 \text { days within } 3,500 \mathrm{ft} \text {. of } \\
\text { longwall mining areas. Events could } \\
\text { occur for } 9-12 \text { years. }\end{array}$ & Same as Alternative B. & $\begin{array}{l}\text { Same as Alternative } B^{\prime} \text { but length of } \\
\text { time that events could occur and be } \\
\text { felt is decreased to } 5-7 \text { years. }\end{array}$ & $\begin{array}{l}\text { Same as Alternative } B^{\prime} \text { but length of } \\
\text { time that events could occur and be } \\
\text { felt is decreased to up to } 7 \text { years. }\end{array}$ \\
\hline
\end{tabular}

Attachment 3, Table 2.2

Page 18 
ATTACHMENT 3

Table 2.2, Comparison of Alternatives, Effects by Resource/Issue (Corrected/Expanded)

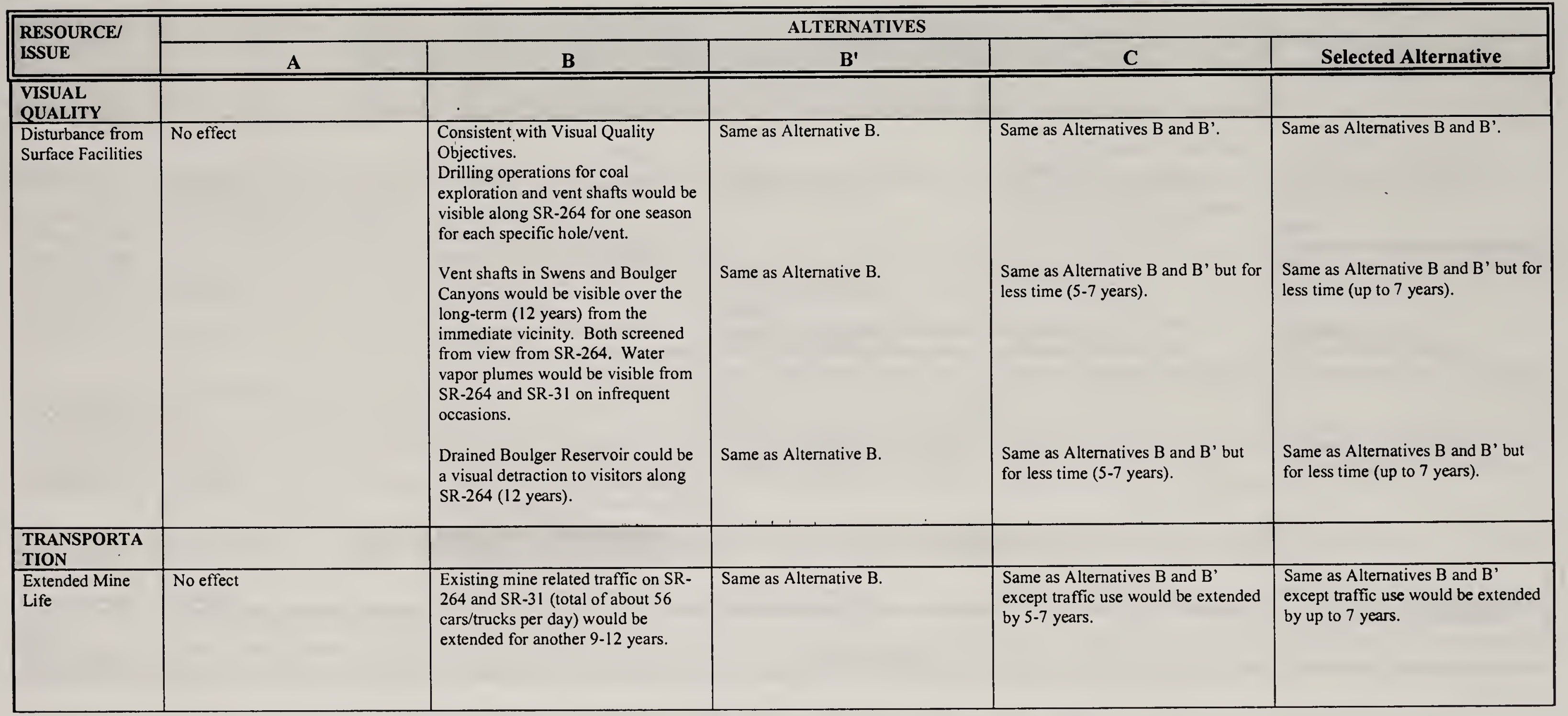

Attachment 3, Table 2.2

Page 19 


\section{ATTACHMENT 3}

Table 2.2, Comparison of Alternatives, Effects by Resource/Issue (Corrected/Expanded)

\begin{tabular}{|c|c|c|c|c|c|}
\hline \multirow{2}{*}{$\begin{array}{l}\text { RESOURCE/ } \\
\text { ISSUE }\end{array}$} & \multicolumn{5}{|c|}{ ALTERNATIVES } \\
\hline & $\mathbf{A}$ & $\mathbf{B}$ & B' & C & Selected Alternative \\
\hline $\begin{array}{l}\text { Disturbance from } \\
\text { Surface Facilities }\end{array}$ & No effect & $\begin{array}{l}\text { Addition of drilling traffic for two - } \\
\text { three seasons (one season for } \\
\text { individual vents/hole) on SR-264, } \\
\text { SR-3l, private roads, and Forest } \\
\text { Development Roads. }\end{array}$ & Same as Alternative B. & Same as Alternatives B and B'. & Same as Alternatives B and B'. \\
\hline Subsidence & No effect & $\begin{array}{l}\text { Minor cracks could occur on SR-264 } \\
\text { that would need repairs. } \\
\text { Larger cracks are expected on Forest } \\
\text { Development roads and private roads } \\
\text { on ridge tops that could present } \\
\text { short-term hazard. } \\
\text { Private roads that cross Flat Canyon } \\
\text { Creek could be flooded requiring } \\
\text { work to raise running surface to } \\
\text { above water levels. }\end{array}$ & $\begin{array}{l}\text { Same as Alternative B. SCLS } \# 13 \\
\text { would require monitoring and repair } \\
\text { of cracks by lessee/operator to avoid } \\
\text { hazards. } \\
\text { Same as Alternative B. SCLS \#13 } \\
\text { would require monitoring and repair } \\
\text { of cracks by lessee/operator to avoid } \\
\text { hazards. } \\
\text { Same as Alternative B. }\end{array}$ & $\begin{array}{l}\text { No effect } \\
\text { Same as Alternative B', except fewer } \\
\text { roads would be subjected to } \\
\text { subsidence. } \\
\text { No effect. }\end{array}$ & $\begin{array}{l}\text { Same as Altemative B', except less } \\
\text { subsidence and decreased potential } \\
\text { for cracks. } \\
\text { Same as Alternative B', except fewer } \\
\text { roads would be subjected to } \\
\text { subsidence. } \\
\text { Same as Alternative B, except less } \\
\text { subsidence and reduced potential for } \\
\text { effects. }\end{array}$ \\
\hline Seismicity & No effect & No effect. & No effect. & No effect. & No effect. \\
\hline
\end{tabular}

Attachment 3, Table 2.2

Page 20 
ATTACHMENT 3

Table 2.2, Comparison of Alternatives, Effects by Resource/Issue (Corrected/Expanded)

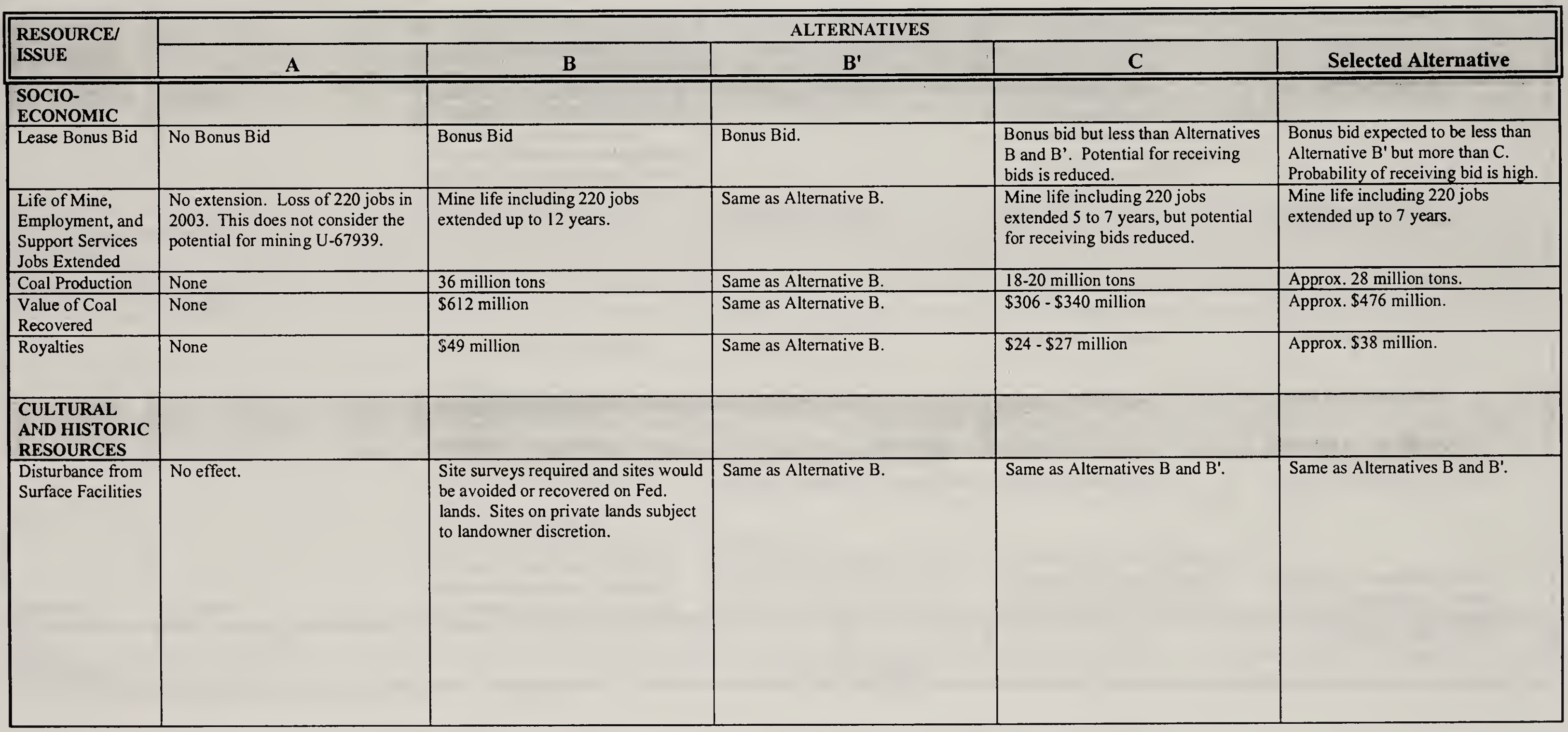

Attachment 3, Table 2.2

Page 21 
ATTACHMENT 3

Table 2.2, Comparison of Alternatives, Effects by Resource/Issue (Corrected/Expanded)

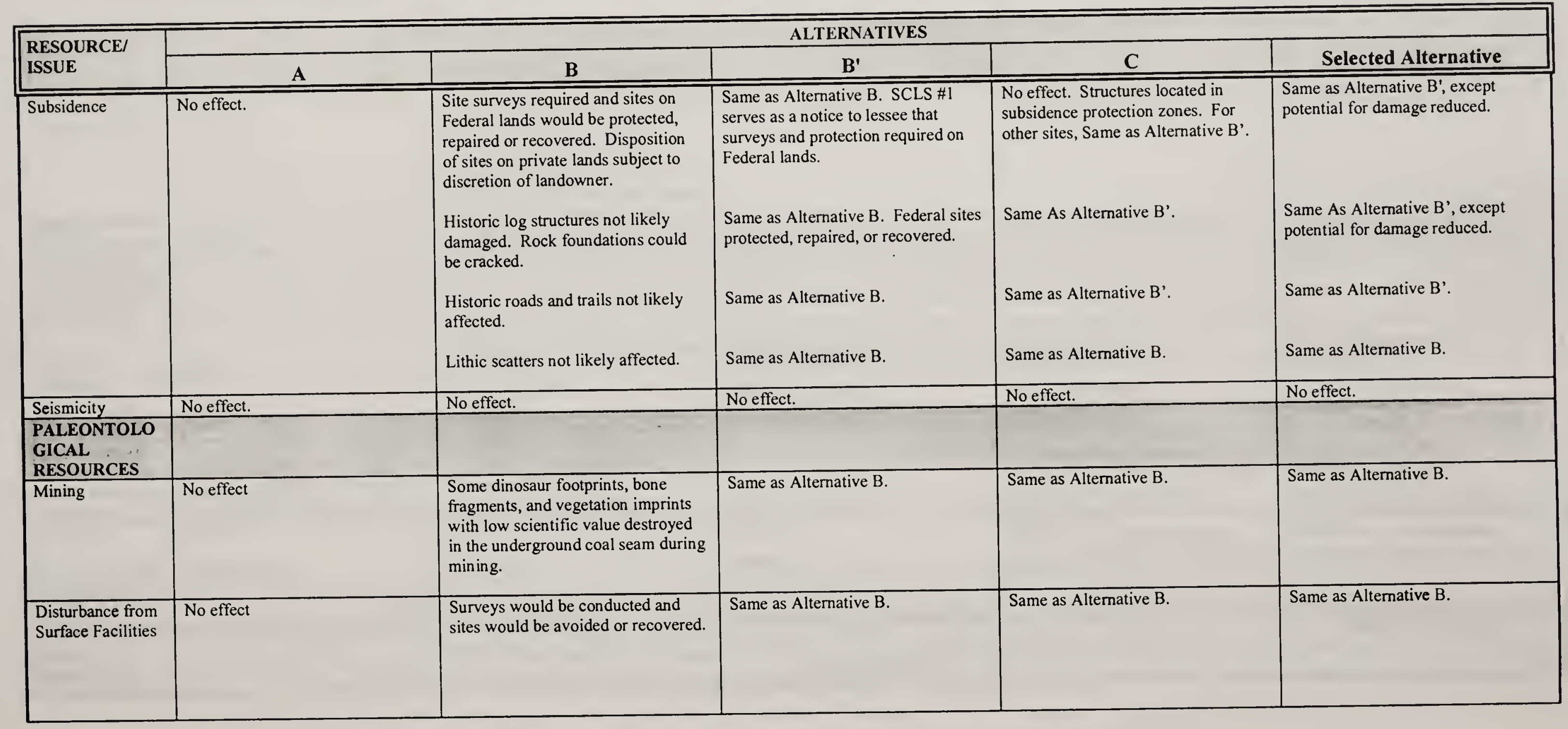

Attachment 3, Table 2.2

Page 22 


\section{Table 2.2, Comparison of Alternatives, Effects by Resource/Issue (Corrected/Expanded)}

\begin{tabular}{|c|c|c|c|c|c|}
\hline \multirow{2}{*}{$\begin{array}{l}\text { RESOURCE/ } \\
\text { ISSUE }\end{array}$} & \multicolumn{5}{|c|}{ ALTERNATIVES } \\
\hline & $\mathbf{A}$ & B & $\mathbf{B}^{\prime}$ & C & Selected Alternative \\
\hline Subsidence & No effect & $\begin{array}{l}\text { No effect to buried dinosaur fossils. } \\
\text { Pleistocene mammal fossils buried } \\
\text { in glacial materials could be } \\
\text { displaced by subsidence. Not likely } \\
\text { that bones would be broken. }\end{array}$ & Same as Alternative B. & $\begin{array}{l}\text { No effect to buried dinosaur fossils. } \\
\text { Very low potential for displacement } \\
\text { of Pleistocene mammal fossils } \\
\text { because high occurrence potential } \\
\text { areas lie within subsidence } \\
\text { protection zones. }\end{array}$ & Same as Alternative B. \\
\hline Seismicity & No effect. & \begin{tabular}{|l} 
No effect. \\
\end{tabular} & No effect. & No effect. & No effect. \\
\hline
\end{tabular}

Attachment 3, Table 2.2

Page 23 



\section{ATTACHMENT 4 FEIS/ROD Mailing List}

Copies of the FEIS and ROD were sent directly to agencies, organizations, and individuals listed below. Copies are also available upon request

\begin{tabular}{|c|c|}
\hline $\begin{array}{l}\text { Director, Planning and Review } \\
\text { Advisory Council on Historic Preservation } \\
1100 \text { Pennsylvania Ave., NW, Suite } 809 \\
\text { Washington, DC } 20004\end{array}$ & $\begin{array}{l}\text { Deputy Director } \\
\text { USDA APHIS PPD/EAD } \\
\text { 4700 River Rd. Unit } 149 \\
\text { Riverdale, MD 20737-1238 } \\
\end{array}$ \\
\hline $\begin{array}{l}\text { Policy and Planning Division } \\
\text { Office of Civil Rights } \\
\text { U.S. Department of Agriculture } \\
\text { Washington, DC } 20250\end{array}$ & $\begin{array}{l}\text { Natural Resources Conservation Service } \\
\text { National Environmental Coordinator } \\
\text { U.S. Department of Agriculture } \\
1400 \text { Independence Ave., SW } \\
\text { Washington, DC } 20250 \\
\end{array}$ \\
\hline $\begin{array}{l}\text { USDA, National Agricultural Library } \\
\text { Head, Acquisitions \& Serials Branch } \\
10301 \text { Baltimore Blvd. Rm. } 002 \\
\text { Beltsville, Maryland } 20705 \\
3 \text { copies }\end{array}$ & $\begin{array}{l}\text { Bureau of Land Management } \\
\text { Utah State Office } \\
\text { P.O. Box } 45155 \\
\text { Salt Lake City, } 84145-0155\end{array}$ \\
\hline $\begin{array}{l}\text { National Marine Fisheries Service } \\
\text { Habitat Conservationists Division } \\
\text { Northwest Region } \\
7600 \text { Sand Point Way NE } \\
\text { BIN C15700, Building 1 } \\
\text { Seattle, WA 98155-0070 } \\
\end{array}$ & $\begin{array}{l}\text { U.S. Army Engr. Northwestern Division } \\
220 \text { N.W. 8th Avenue } \\
\text { Portland, OR 97209-3589 }\end{array}$ \\
\hline $\begin{array}{l}\text { Director, Office of Environmental Compliance } \\
\text { U.S. Department of Energy } \\
1000 \text { Independence Ave., SW } \\
\text { Mail Code EH-22, Rm. 3G092 } \\
\text { Washington, DC } 20585 \\
\text { 3 copies }\end{array}$ & $\begin{array}{l}\text { Region VIII Environmental Protection Agency } \\
\text { EIS Review Coordinator } \\
1 \text { Denver Place, Suite } 500 \\
99918 \text { th St. } \\
\text { Denver, CO } 80202 \\
5 \text { copies } \\
\end{array}$ \\
\hline $\begin{array}{l}\text { Environmental Officer } \\
\text { U.S. Department of Housing \& Urban Development } \\
63317 \text { th Street } \\
\text { Denver, CO } 80202\end{array}$ & $\begin{array}{l}\text { Director, Office of Environmental Policy and } \\
\text { Compliance } \\
\text { U.S. Department of Interior } \\
\text { Main Interior Bldg., MS-2340 } \\
1849 \text { C Street, NW } \\
\text { Washington, DC } 20240 \\
9 \text { copies }\end{array}$ \\
\hline $\begin{array}{l}\text { Chief, Energy and Environment } \\
\text { Interstate Commerce Commission } \\
\text { Rm. } 3219 \\
\text { Washington, DC } 20423\end{array}$ & $\begin{array}{l}\text { Intermountain Region } \\
\text { National Park Service } \\
12795 \text { Alameda Parkway } \\
\text { Lakewood, CO } 80225 \\
\end{array}$ \\
\hline
\end{tabular}




\begin{tabular}{|c|c|}
\hline $\begin{array}{l}\text { Assistant Secretary for Policy } \\
\text { Environmental Division (P-14), Rm. } 9217 \\
400 \text { 7th Street, SW } \\
\text { Washington, DC } 20593\end{array}$ & $\begin{array}{l}\text { Northwest Mountain Region } \\
\text { Regional Administrator } \\
\text { Federal Aviation Administration } \\
1601 \text { Lind Avenue, SW } \\
\text { Renton, WA 98055-4056 } \\
\end{array}$ \\
\hline $\begin{array}{l}\text { Western Region, Regional Administrator } \\
\text { Federal Highway Administration } \\
201 \text { Mission St., Suite } 2100 \\
\text { San Francisco, CA } 94105\end{array}$ & $\begin{array}{l}\text { Office of Transportation and Regulatory Affairs } \\
\text { Federal Railroad Administration } \\
\text { Environmental Division, P-14 } \\
4007 \text { th Street, SW } \\
\text { Washington, DC } 20590 \\
\end{array}$ \\
\hline $\begin{array}{l}\text { Research and Special Program Administration } \\
\text { Federal Railroad Administration } \\
4007 \text { th Street, SW } \\
\text { Washington, DC } 20590\end{array}$ & $\begin{array}{l}\text { Floyd McMullen } \\
\text { Office of Surface Mining } \\
1999 \text { Broadway, Suite } 3320 \\
\text { Denver, Colorado } 80202 \\
2 \text { copies } \\
\end{array}$ \\
\hline $\begin{array}{l}\text { Carl Winters } \\
\text { Canyon Fuel Company, LLC } \\
\text { HC 35, Box } 380 \\
\text { Helper, Utah } 84526\end{array}$ & \begin{tabular}{|l} 
Laura Lindley \\
Bjork, Lindley, Danielson \& Baker, P.C. \\
Attourneys at Law \\
1600 Stout Street, Suite 1400 \\
Denver, Colorado 80202 \\
\end{tabular} \\
\hline Mark Belles & Brian Trapnell \\
\hline $\begin{array}{l}\text { Carl Adams } \\
\text { Utah Division of Water Quality } \\
\text { P.O. Box } 144870 \\
\text { Salt Lake City, Utah } 84118-4870\end{array}$ & Elmer Fellis \\
\hline $\begin{array}{l}\text { JD (Jeff) McKenzie, PE } \\
\text { The Church of Jesus Christ of Latter-day Saints } \\
\text { Natural Resource Section } \\
\text { Twelfth Floor East, Room } 1229 \\
50 \text { East North Temple Street } \\
\text { Salt Lake City, Utah 84150-0001 }\end{array}$ & Ken Bench \\
\hline $\begin{array}{l}\text { Eddie Cox } \\
\text { Sanpete County Commission Chair } \\
\text { Sanpete County Courthouse } \\
160 \text { North Main } \\
\text { Manti, Utah } 84642\end{array}$ & Lee Cox \\
\hline
\end{tabular}




\begin{tabular}{|c|c|}
\hline $\begin{array}{l}\text { Miles Moretti } \\
\text { State of Utah } \\
\text { Department of Natural Resources } \\
\text { Division of Wildlife Resources } \\
1594 \text { West North Temple, Suite } 2110 \\
\text { P.O. Box } 146301 \\
\text { Salt Lake City, Utah } 84114-6301 \\
\end{array}$ & Odell Cox \\
\hline $\begin{array}{l}\text { Kevin Christopherson } \\
\text { Regional Supervisor } \\
\text { State of Utah } \\
\text { Department of Natural Resources } \\
\text { Division of Wildlife Resources } \\
\text { Southeastern Region } \\
475 \text { West Price River Drive, Suite C } \\
\text { Price, Utah } 84501-2860\end{array}$ & LaMont Christensen \\
\hline $\begin{array}{l}\text { Reed Harris } \\
\text { Field Supervisor } \\
\text { United States Department of the Interior } \\
\text { Fish and Wildlife Service } \\
\text { Utah Field Office } \\
\text { Lincoln Plaza } \\
145 \text { East } 1300 \text { South, Suite } 404 \\
\text { Salt Lake City, Utah } 84115\end{array}$ & Newell Dee Cox \\
\hline $\begin{array}{l} \\
\text { Conrad Houser } \\
\text { NorWest Mine Services, Inc. } \\
\text { 136 East South Temple, 12th. Floor } \\
\text { Salt Lake City, Utah } 84111 \\
\end{array}$ & C.C. Dixon Trustee \\
\hline $\begin{array}{l}\text { Mark Page } \\
\text { Regional Engineer } \\
\text { State of Utah } \\
\text { Department of Natural Resources } \\
\text { Division of Water Rights } \\
\text { Southeastern Area } \\
\text { 453 South Carbon Avenue } \\
\text { P.O. Box } 718 \\
\text { Price, Utah } 84501-0718\end{array}$ & $\begin{array}{l}\text { Kelly Payne } \\
\text { NorWest Mine Services, Inc. } \\
\text { 136 East South Temple, 12th Floor } \\
\text { Salt Lake City, Utah } 84111\end{array}$ \\
\hline $\begin{array}{l}\text { Jack Stoyanoff } \\
\text { Manager N.E.W.U.A } \\
\text { North Emery Water Users Association } \\
1325 \text { North Highway } 155 \\
\text { Box } 129 \\
\text { Cleveland, Utah } 84518 \\
435-653-2649\end{array}$ & \begin{tabular}{|l|} 
Erik Petersen \\
Petersen Hydrologic \\
2695 North 600 East \\
Lehi, Utah 84043 \\
\end{tabular} \\
\hline
\end{tabular}




\begin{tabular}{|c|c|}
\hline $\begin{array}{l}\text { Craig Axford } \\
\text { Program Director } \\
\text { Utah Environmental Congress } \\
1817 \text { S. Main Street; Suite } 9 \\
\text { Salt Lake City, Utah } 84115 \\
\end{array}$ & $\begin{array}{l}\text { Leigh J. Kuwanwisiwma } \\
\text { Director Cultural Preservation Office } \\
\text { The Hopi Tribe } \\
\text { P.O. Box } 123 \\
\text { Kykotsmovi, Arizona } 86039 \\
\end{array}$ \\
\hline $\begin{array}{l}\text { John Carter } \\
\text { President } \\
\text { Willow Creek Ecology } \\
\text { P.O. Box 280, Mendon, Utah } 84325 \\
\end{array}$ & Robert Jewkes \\
\hline $\begin{array}{l}\text { Richard Bennett } \\
\text { ROM Coal News } \\
\text { Lis Cartan Hous } \\
127 \text { Sloane Street } \\
\text { London, UK } \\
\text { SW1X9BA }\end{array}$ & Greg Shaefer \\
\hline $\begin{array}{l}\text { Jack Rogers } \\
\text { LASR Geo Consulting } \\
50 \text { E. } 970 \text { N. } \\
\text { Castle Dale, Utah } 84513\end{array}$ & $\begin{array}{l}\text { Darrell Leamaster } \\
\text { Castle Valley Special Services District } \\
\text { P.O. Box } 877 \\
\text { Castle Dale, Utah } 84513\end{array}$ \\
\hline $\begin{array}{l}\text { Jay Mark Humphrey } \\
\text { Emery Water Conservancy District } \\
50 \text { E. } 100 \text { S. } \\
\text { P.O. Box } 998 \\
\text { Castle Dale, Utah } 84513 \\
\end{array}$ & $\begin{array}{l}\text { Jeff Richens } \\
\text { Price Water Improvement District } \\
265 \text { Fairgrounds Road } \\
\text { Price, Utah } 84501\end{array}$ \\
\hline $\begin{array}{l}\text { Varden Wilson } \\
\text { Huntington-Cleveland Irrigation Company } \\
\text { P.O. Box } 327 \\
\text { Huntington, Utah } 84528\end{array}$ & $\begin{array}{l}\text { Kleston Laws } \\
\text { Utah Department of Transportation } \\
\text { Rt. \#3 Box 75C5 } \\
940 \text { S. Carbon Avenue } \\
\text { Price, Utah } 84501 \\
\end{array}$ \\
\hline $\begin{array}{l}\text { Mary Ann Wright } \\
\text { Utah Department of Natural Resources } \\
\text { Division of Oil, Gas and Mining } \\
1594 \text { West North Temple, Suite } 1210 \\
\text { P.O. Box } 145801 \\
\text { Salt Lake City, Utah } 84114-5801 \\
\end{array}$ & $\begin{array}{l}\text { Carbon County Commissioners } \\
\text { Carbon County Courthouse } \\
120 \text { E. Main } \\
\text { Price, Utah } 84501\end{array}$ \\
\hline $\begin{array}{l}\text { Emery County Commissioners } \\
\text { P.O. Box } 629 \\
\text { Castle Dale, Utah } 84513 \\
\end{array}$ & $\begin{array}{l}\text { Utah County Commissioners } \\
100 \text { E. Center Street } \\
\text { Provo, Utah } 84601 \\
\end{array}$ \\
\hline $\begin{array}{l}\text { Juab County Commissioners } \\
146 \text { North Main } \\
\text { Nephi, Utah } 84648\end{array}$ & $\begin{array}{l}\text { Mayor of Scofield } \\
\text { Scofield Town } \\
\text { Scofield Rt. } \\
\text { Helper, Utah } 84526\end{array}$ \\
\hline
\end{tabular}




\begin{tabular}{|l|l|}
\hline Val Payne & Charles A. Calhoun \\
Emery County Public Lands Council & U.S. Bureau of Reclamation \\
P.O. Box 1298 & Upper Colorado Regional Office \\
Castle Dain & 125 South State, Room 6107 \\
& Salt Lake City, Utah 84138 \\
\hline & \\
\hline Price River Water Users & US Environmental Protection Agency \\
90 N. 100 E. & Office of Federal Activities \\
Price, Utah 84501 & Mail Code 2252-A, Room 7241 \\
& Ariel Rios Building (South Oval Lobby) \\
& 1200 Pennsylvania Avenue, NW \\
& Washington, DC 20004 \\
& 5 copies \\
\hline
\end{tabular}




\section{BLM Library \\ Denver Federal Center \\ Bldg. 50, OC-521 \\ P.O. Box 25047 \\ Denver, CO 80225}

